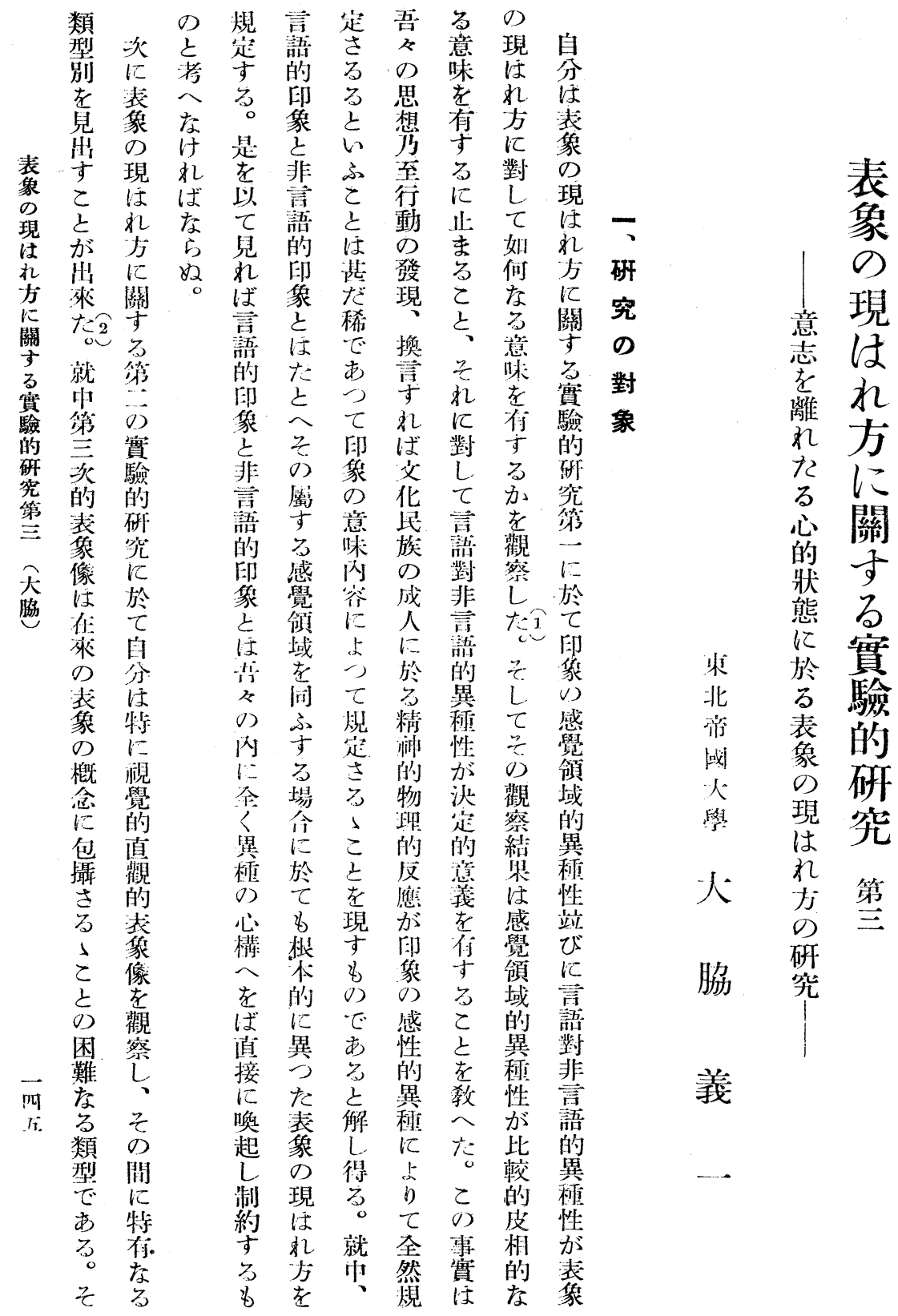




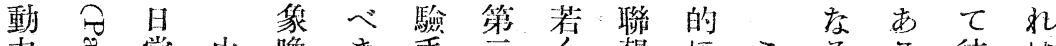

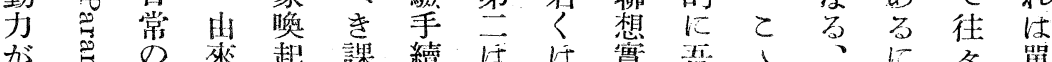

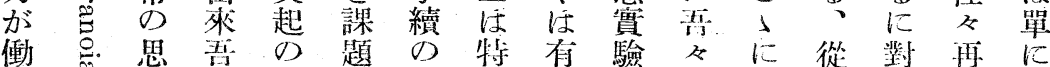
几さ惟々意の,上飞意、の於て

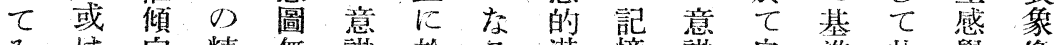
わは向精無識於る 潜憶識自準此覺像心

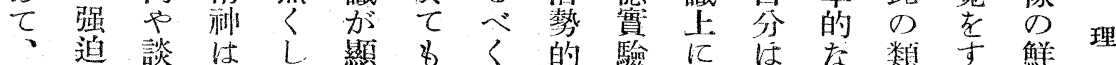
そ觀 話 吾 乙 在 特自心其出更方型ら 明學 狆念沶冬現的に然構他 のに年は自此のへ二來一態表隨が研

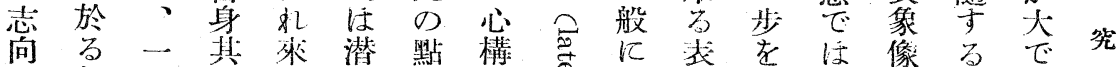

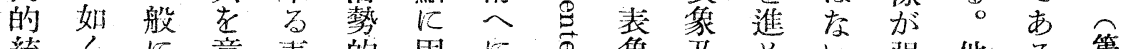

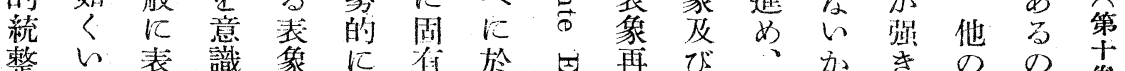

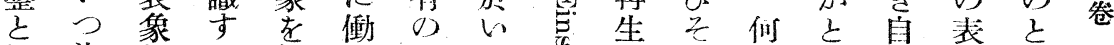

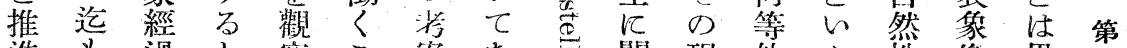

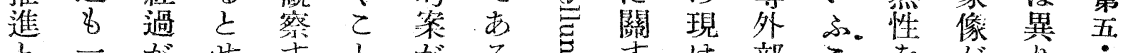
が 事條 ざ る

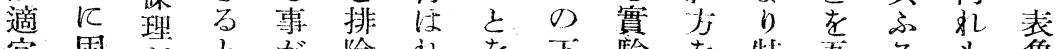
宜固がとが除礼老下驗老特韋る る 售 に着泫に, 表した强に的探别々とたで

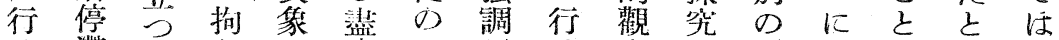
は滯てらの方でしは察せ印荐はへあ

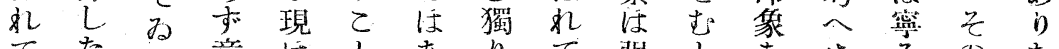

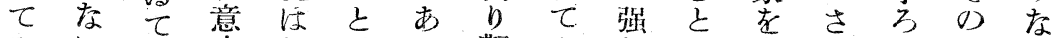

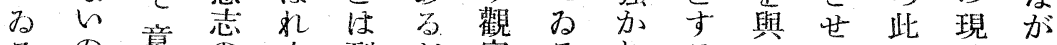
るの意の方到が察るれるへた

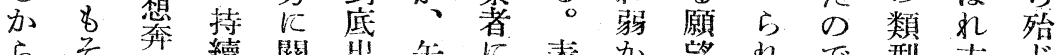

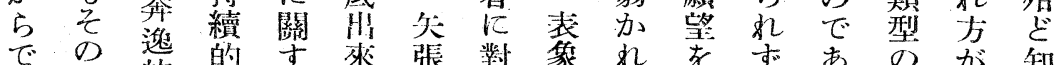

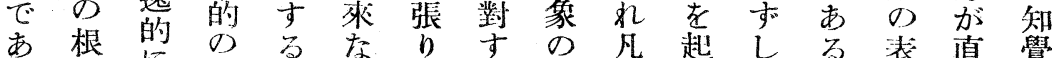

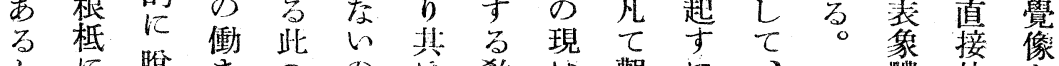

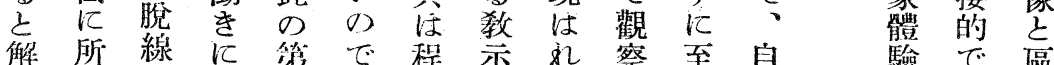

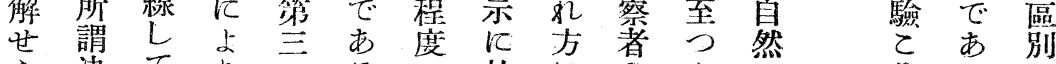

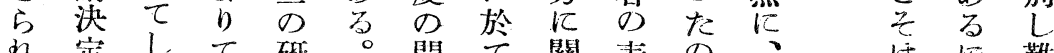

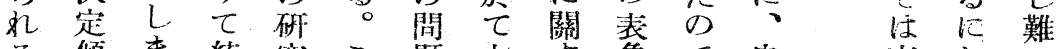
る傾ま統究乙題少㨙で自表 L 向は 整の の で 說る 索あ 己 象て 如一

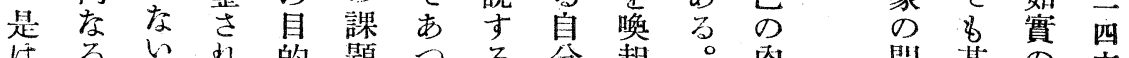

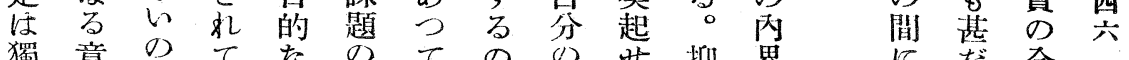

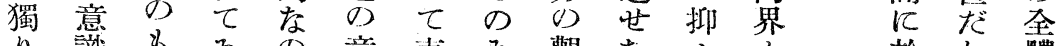

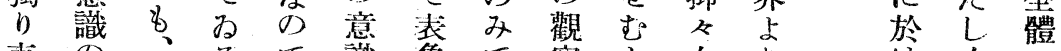

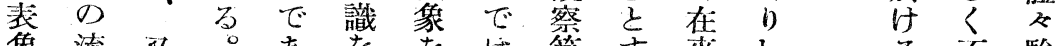

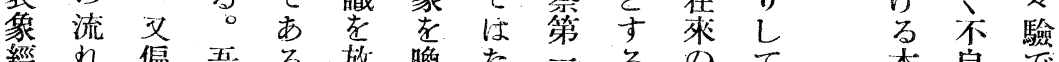

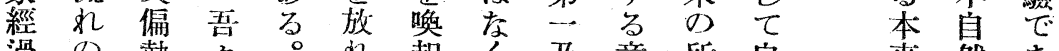

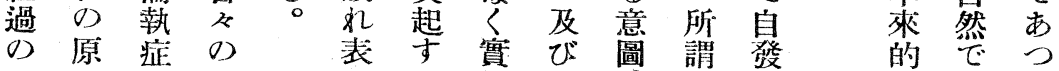




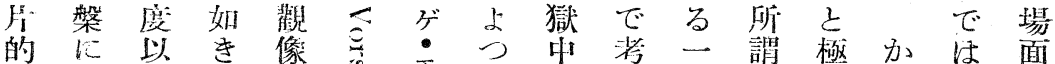

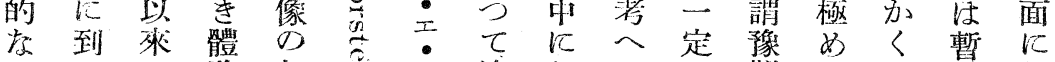

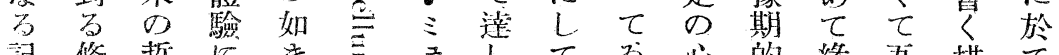

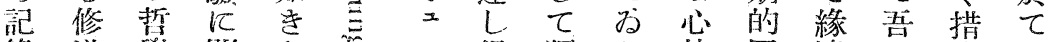

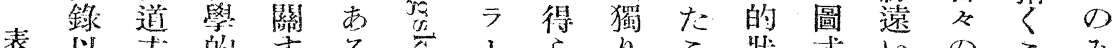

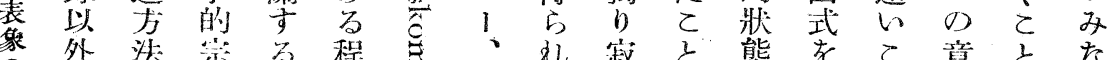

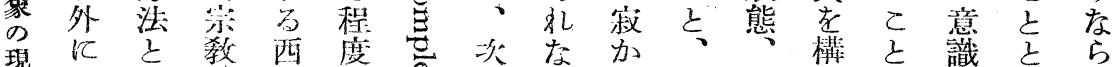

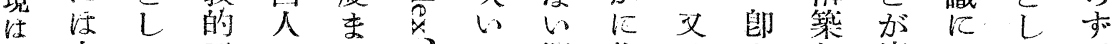
扎未て 宾ので、で洞物は古し唐現よ吾

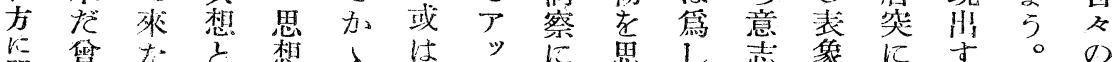

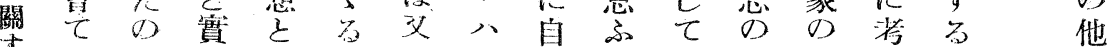

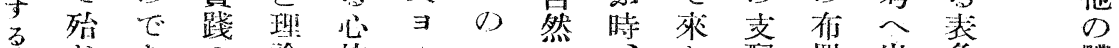

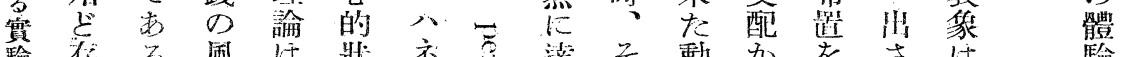

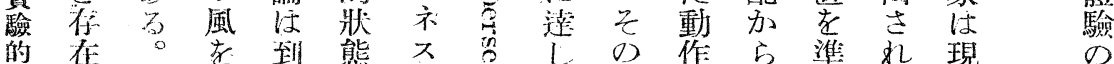

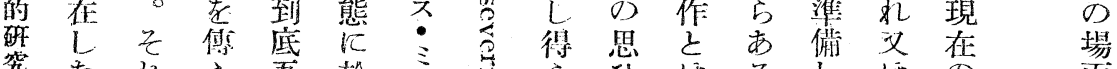

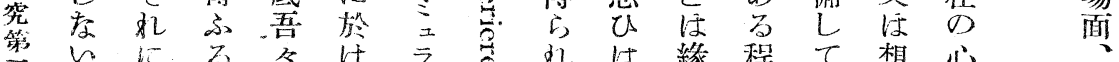

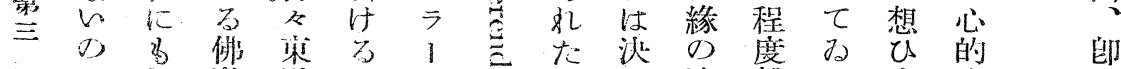

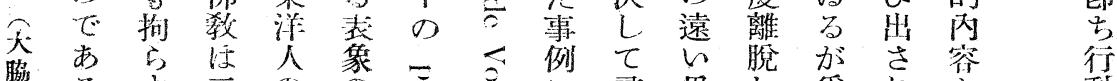

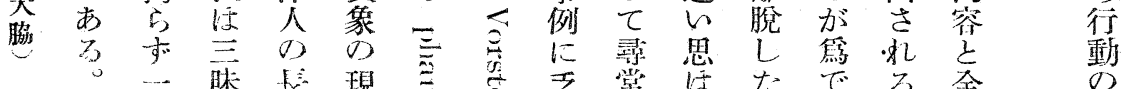

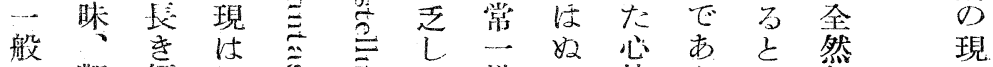

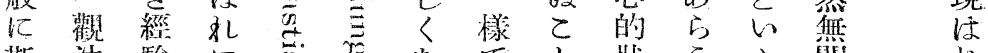

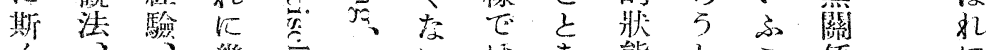

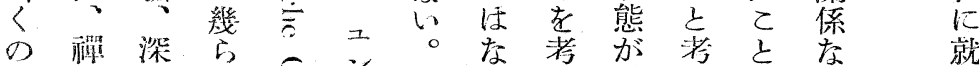

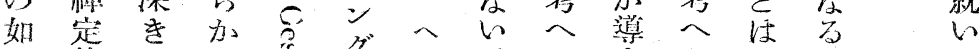

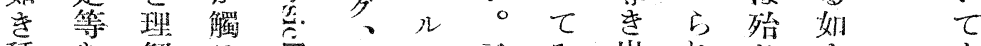

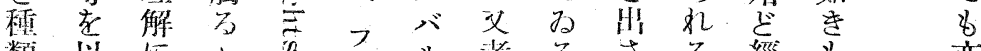

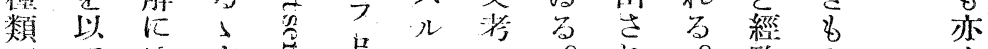

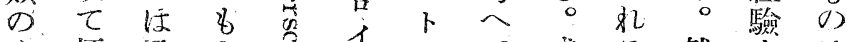

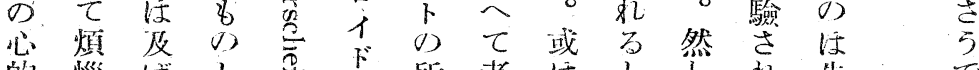

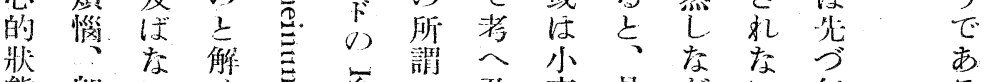
態郘

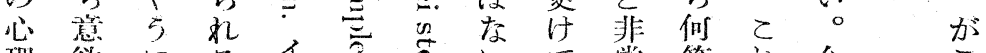

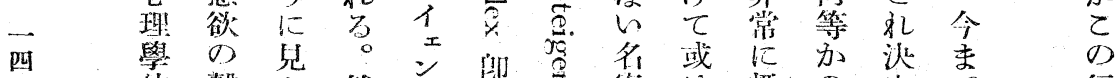

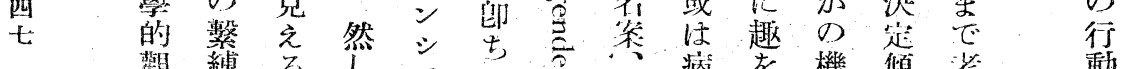

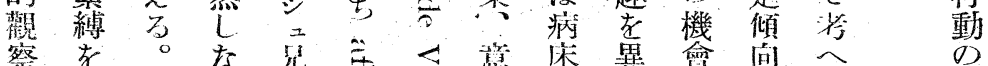

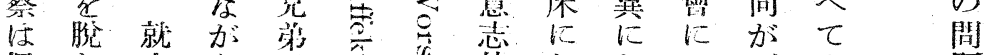

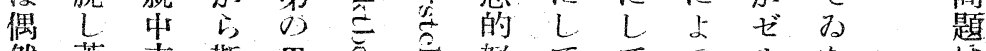

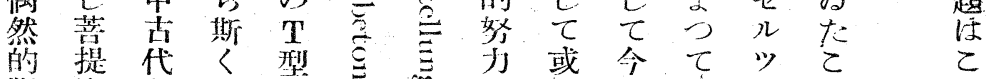

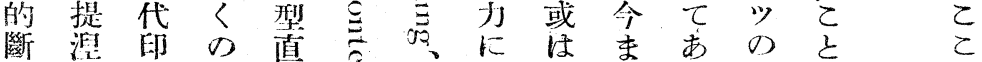


掛汇態仕乙方办

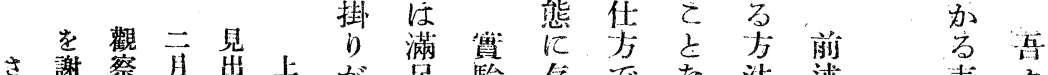

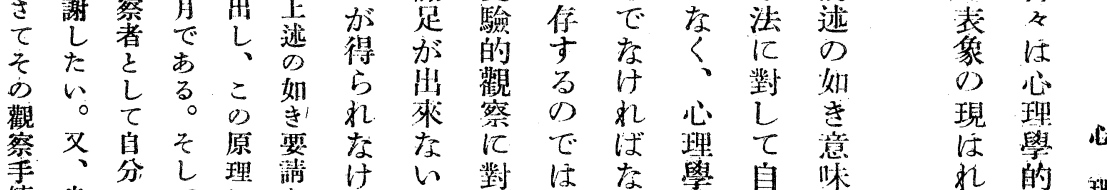

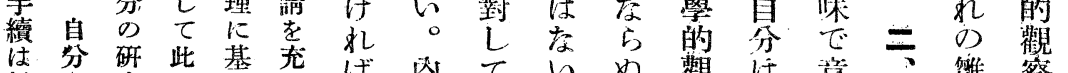

極分究

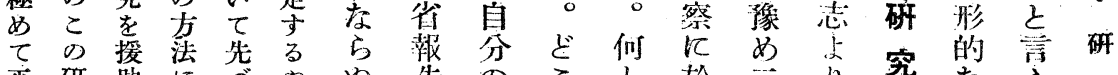

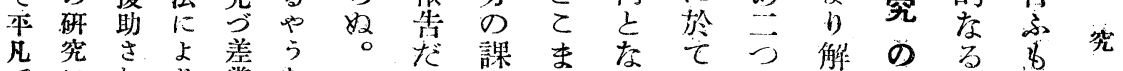
でに机り當な あ 對 た 或り 欟 るして安 る 觀导蔗實續 繁直郎妾驗き は間、所續就

接阿期壳

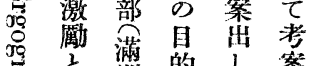

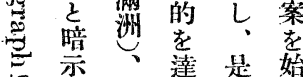
にを太艺を是始 上 與 田 得 - た る 人代る人の 極ら、見のは く扎相透 觀 昭 簡た澤し察利 小葉北つに年

且糹村 $い$ 就 殆先北 たて

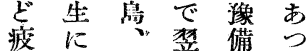
筫 深 櫻年苗た 起并に驗。 伴感のなをを は謝 諸つ施の なの氏て行內

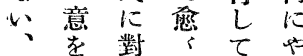
グ袁主正 み

刃るこ狄方觀至

ル第に觀至方

なで厚を等の法

筋あく始は的

闪当々女间原

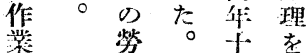

け L で就普の放

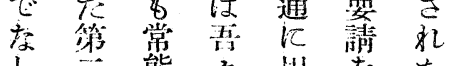

L -... 態々 川索た

にの人の立課宁

们要の闃らし心

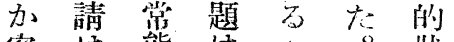

客は態は小。㠺

觀 斯 心 決 如 乞 態

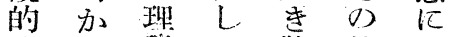

にる 學 $\tau$ 裝 篗 於

力心の 斯 置 $\cdots$ 方

为它筫籍

法老紙卷

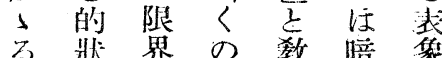

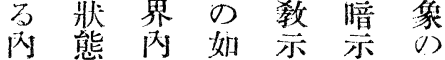

的のにを在と現

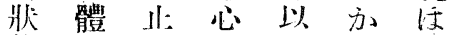

態驗 つ 的七催犯

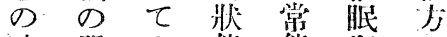

時骂妿熊態街老

清门云に众的ば

的主の就㤎方筫

經 磪でい畫 法 驗

過的 あて 驗と的

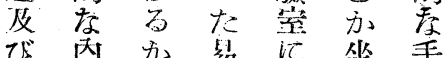

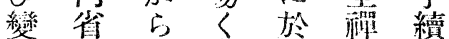

動的で聯てととき

の 偲市想自吕に

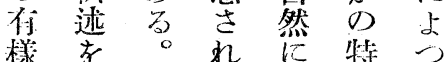

考得名喚㷠七

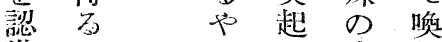

識と 5 さ方起

L 之 桀机法

得だ異吕に覞

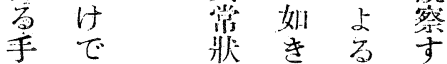

越

第

而坴范

組谳 輯

織 的

的 $f_{j}$

几 法

if K

碓 唯

精 る

密 こ

欟质

察〈

于 何

子

过

䨘

乘 驗

疾的

( 与

で 法

あ

5 上

5 b

加

装澅

人 的

店保 


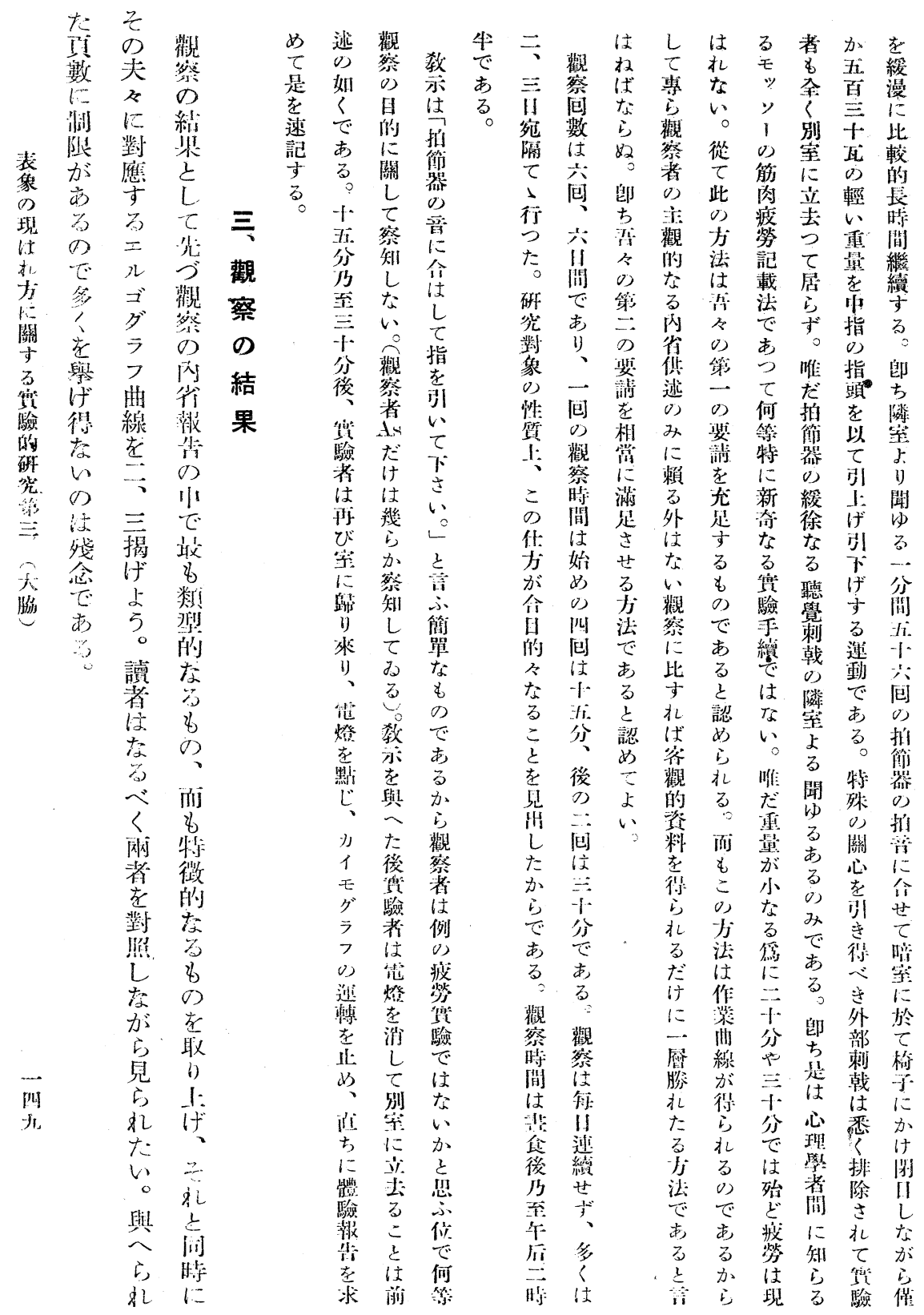




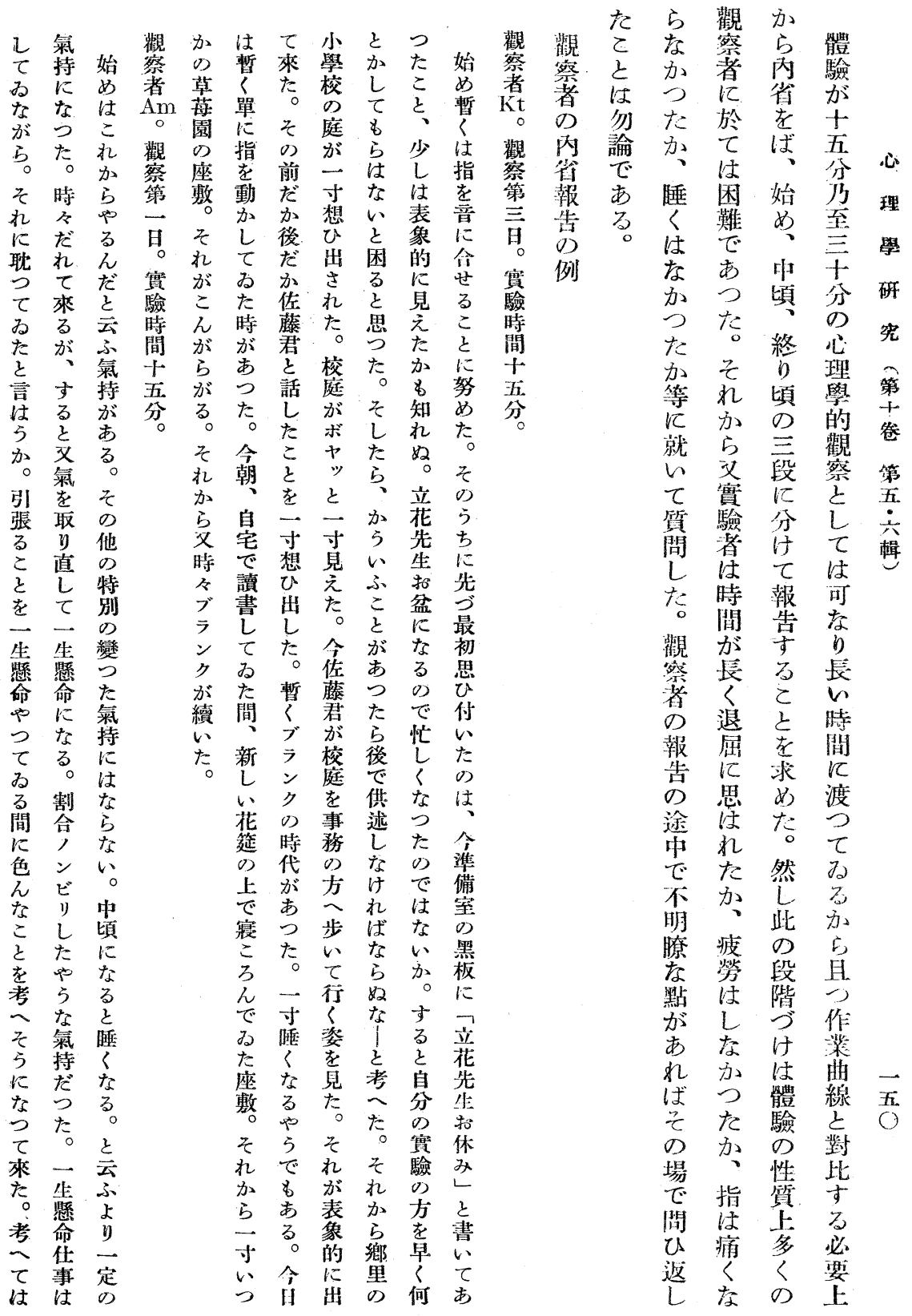




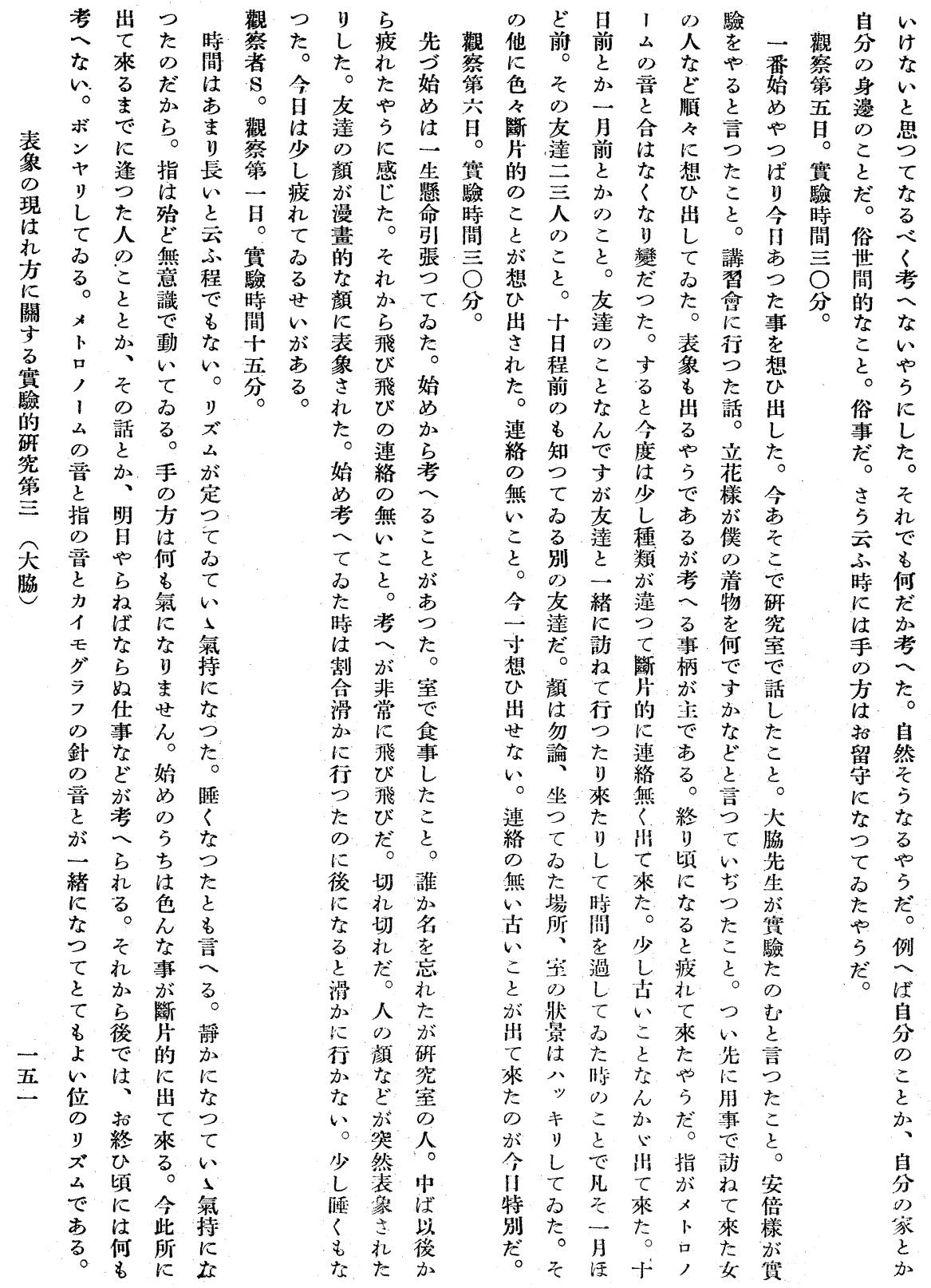




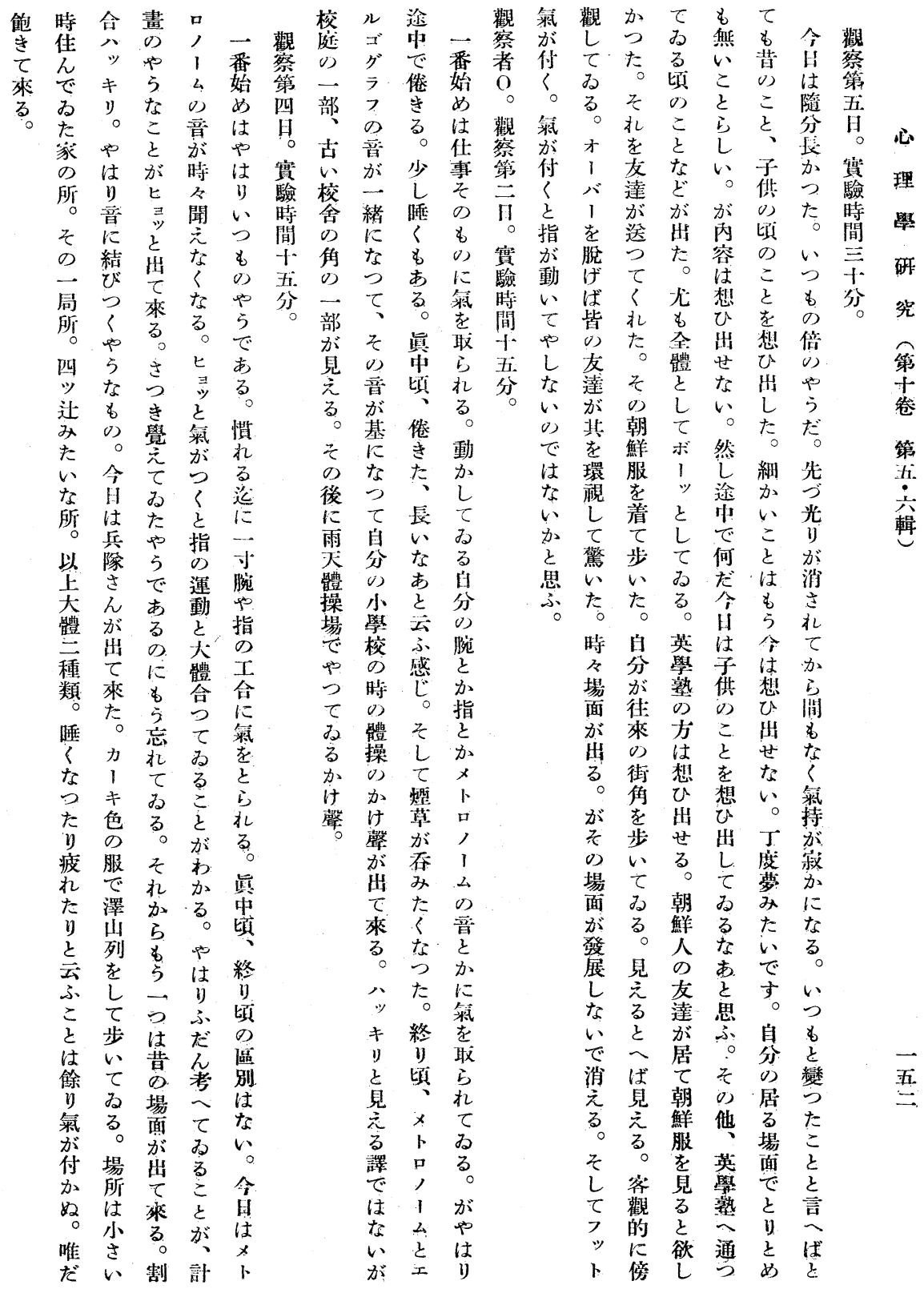




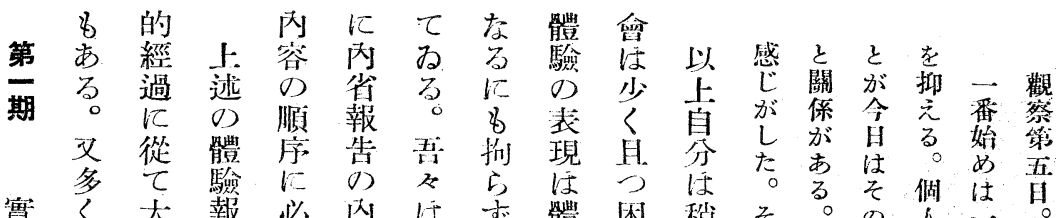

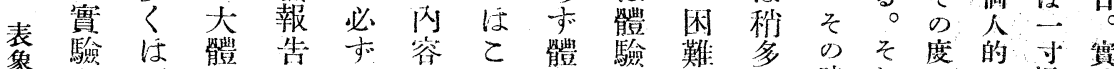

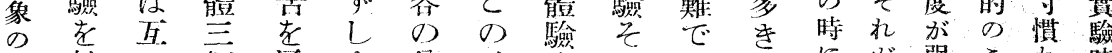

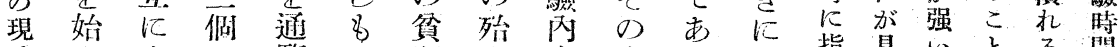

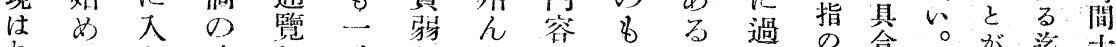

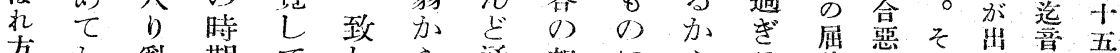

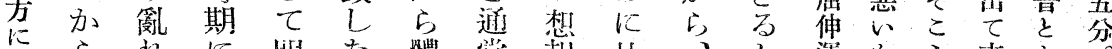

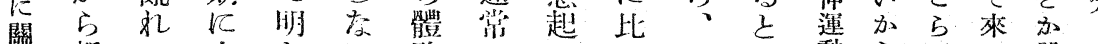

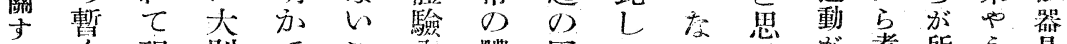

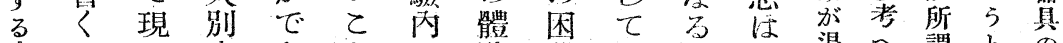

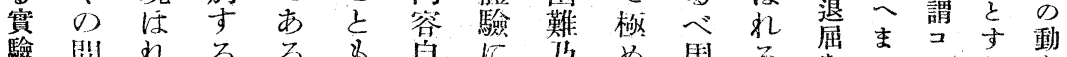

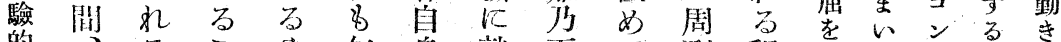

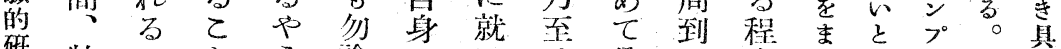
研特のとう論の特に筧に多ぎすと出会 第にでがにで盆て不弱認數らるるてに

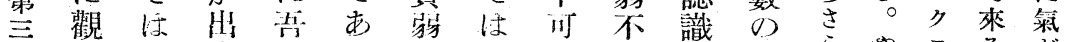

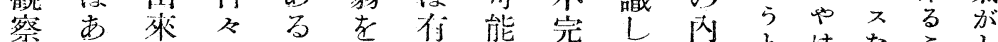

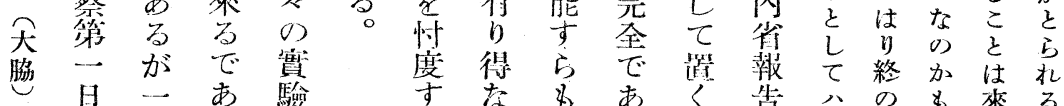

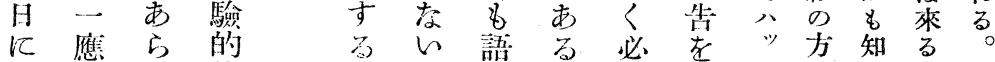

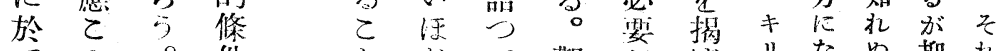

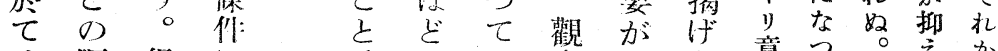

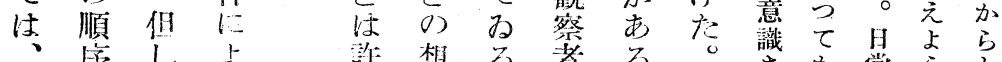

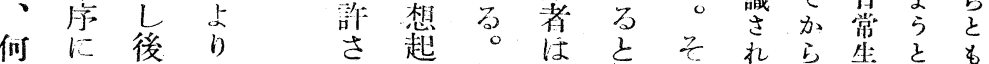

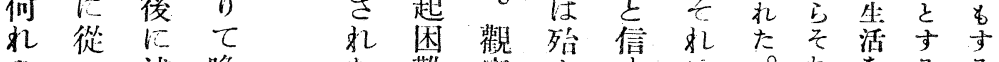

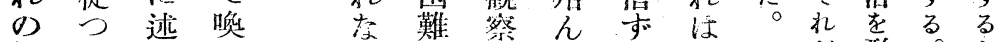

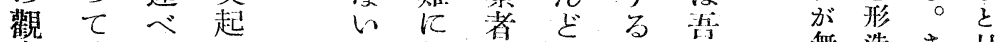

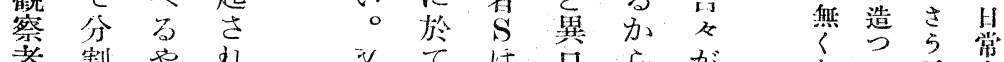
者製や狄 义て

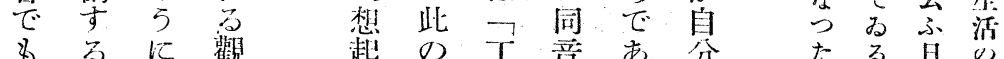

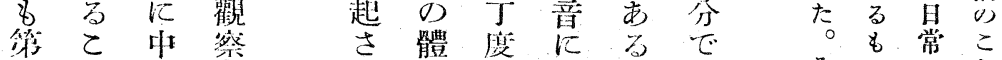

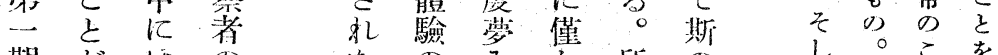

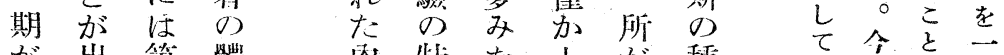

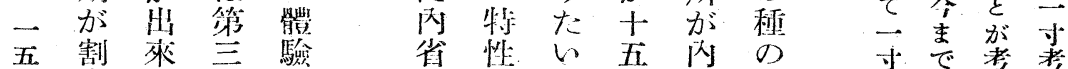
三合吕期 の 記ので分省體退家へつ 長。芕述…す後詰驗屈でらよ

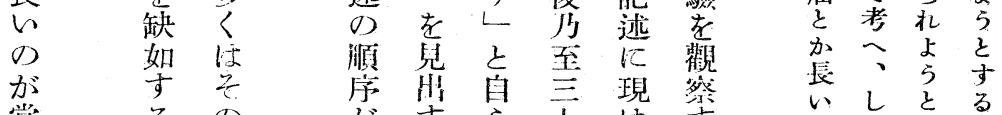

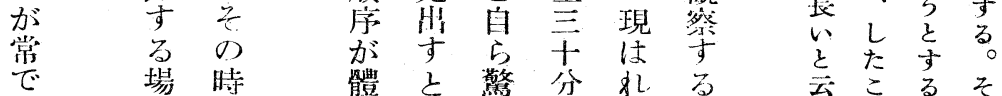

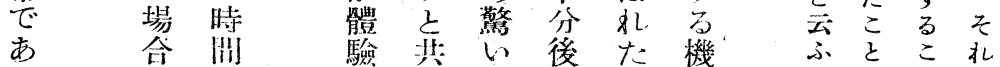




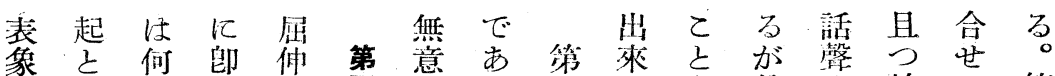

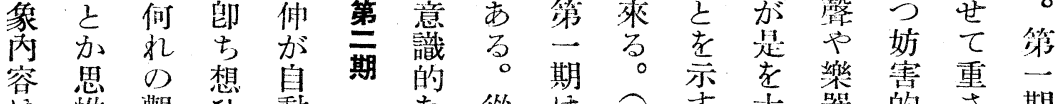

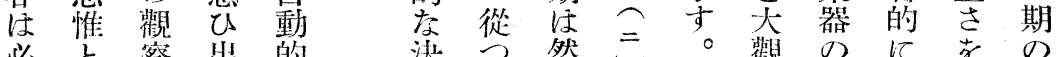

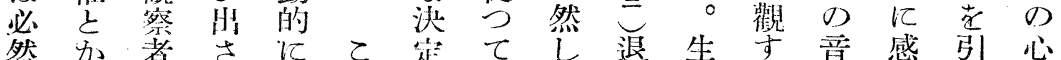

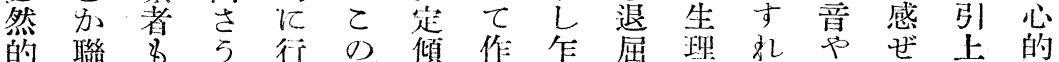

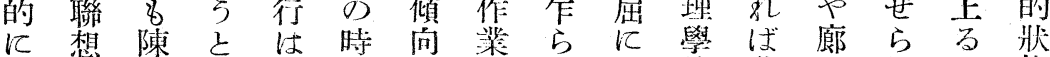

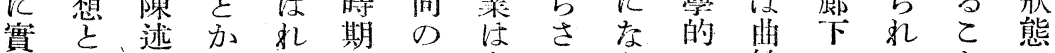

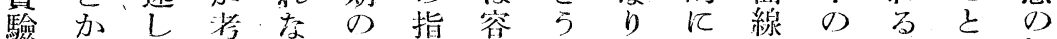

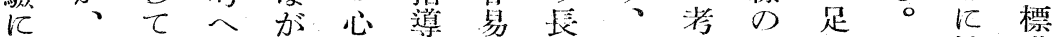

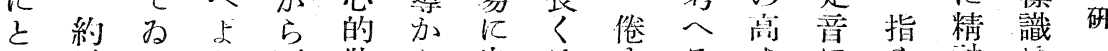

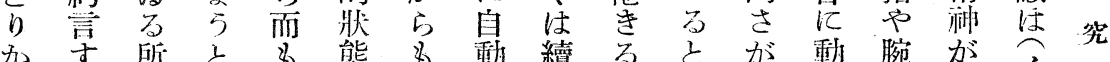

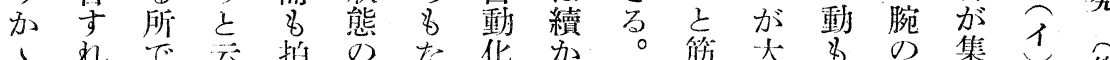

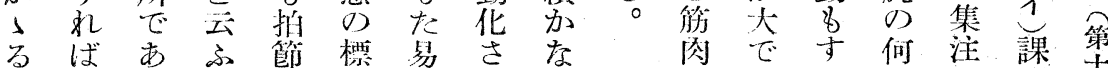

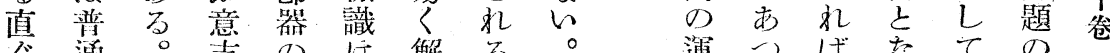

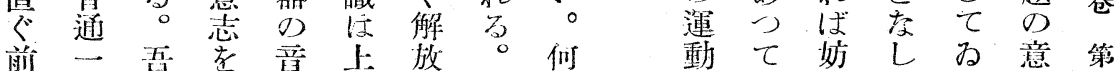

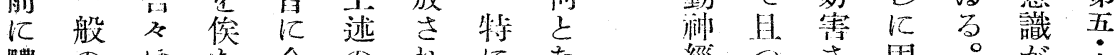
體のほた合の狄に委經つさ固。が

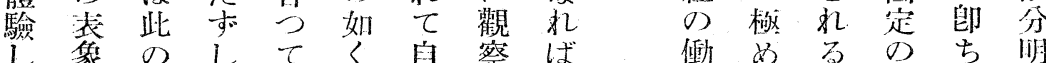

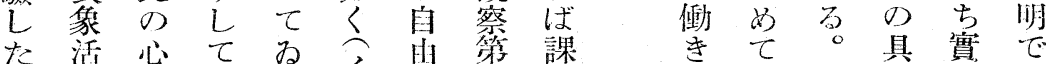
所動的表名过江題均合驗あ

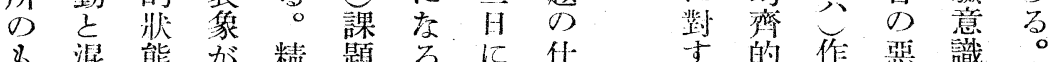

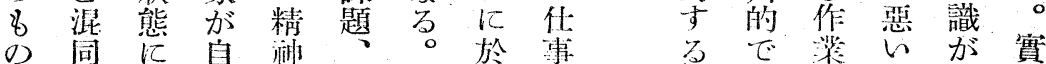
です於發、は 從即て医市曲て 磼驗

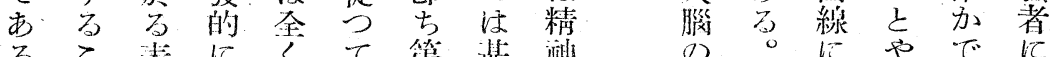

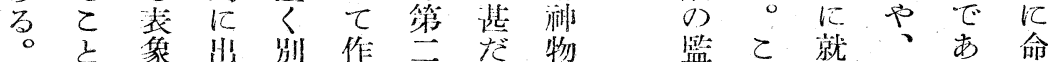

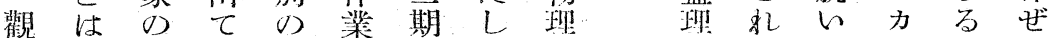

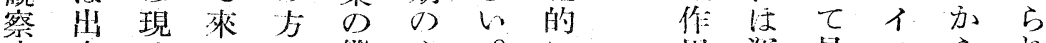

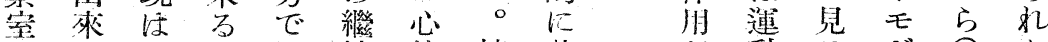

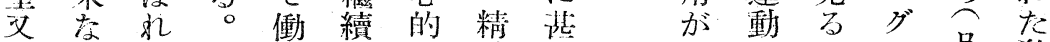

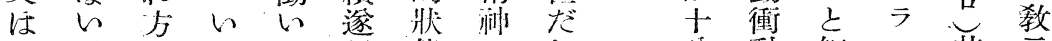

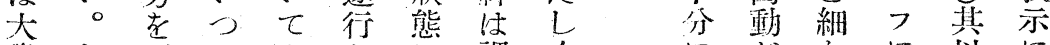

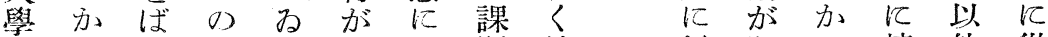

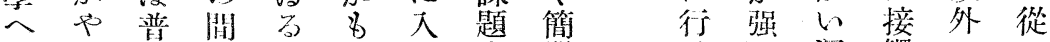

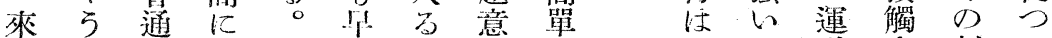

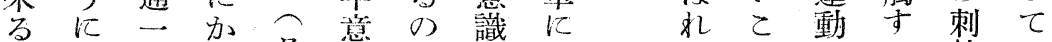

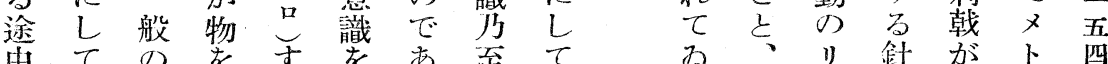

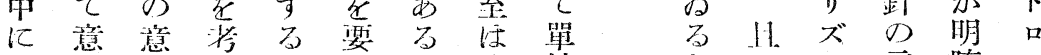

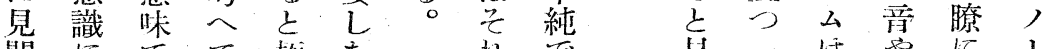

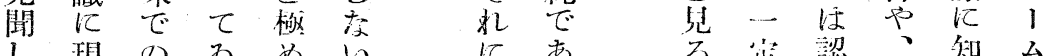

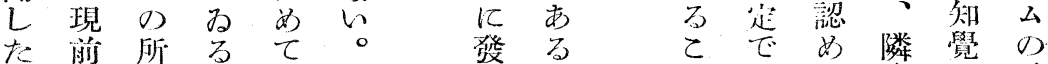

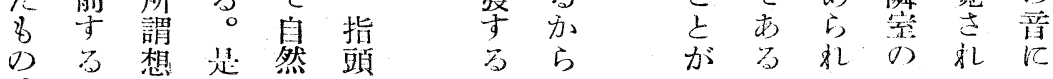
心 理 學 f . 


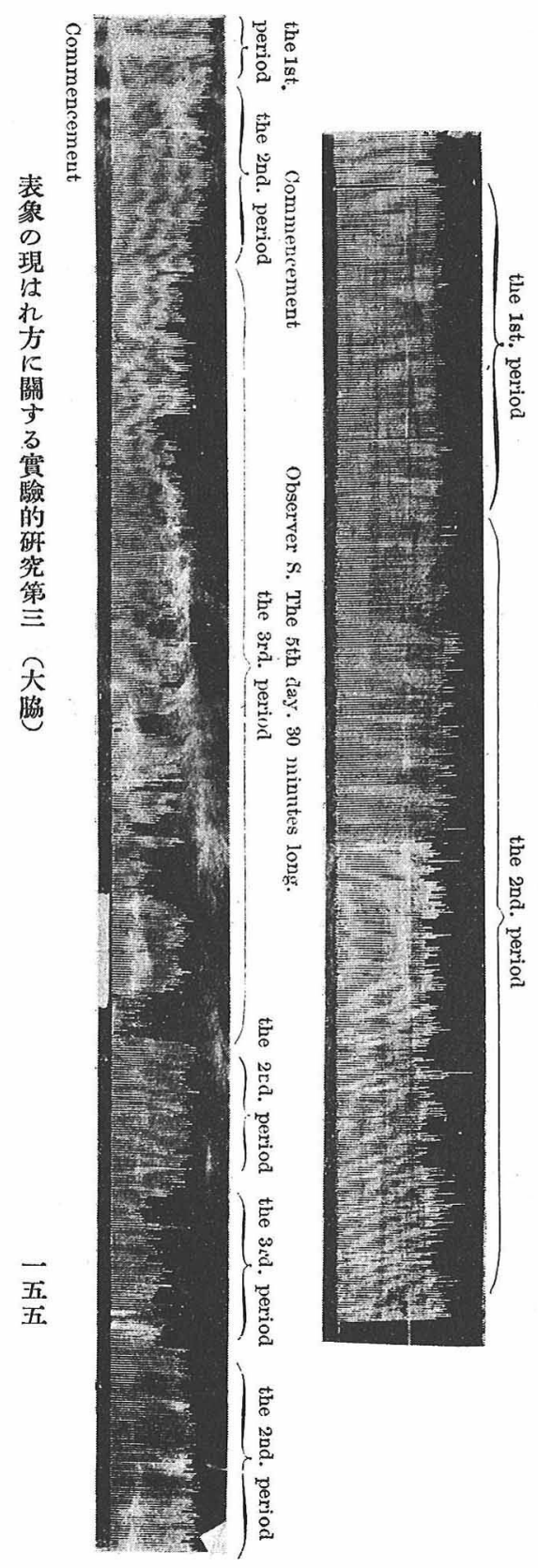

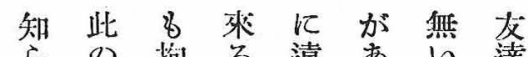

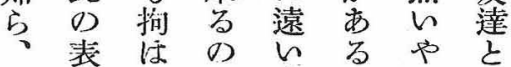

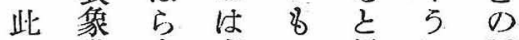
D隻和表の思に話 事行不像核本題

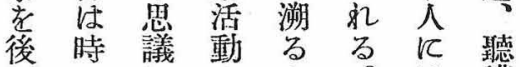

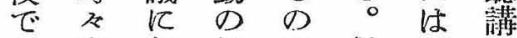
冈䨘想最で最思し

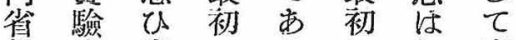
報意出の方氏來 告識せ率ら現るた 怘な發しは。講 疗䈆 $心$ 點 けに・の。るL丙 五れ中從所けの調容 滵ば斷つでれは查等 索さて あど最しで

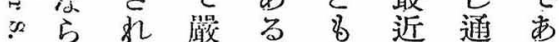
崖如る密。公の覽る

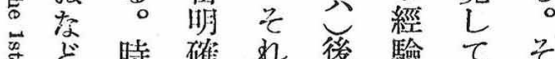

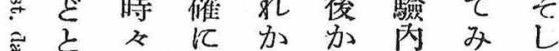

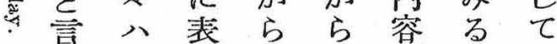

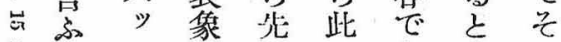
意之進の的必 識 $L$ 行進體主表

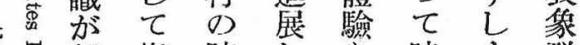
客起指跡 ᄂ 時的群

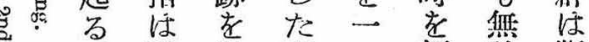
。動 辿表及經秩斷 之名集想方序所 ᄂ $\tau$ 事离起飞で的 てみは容す從はで

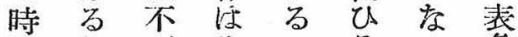

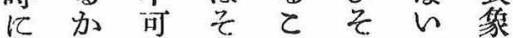
任知能分狆。活 そらで當活少少動 の、西時恐 らくの

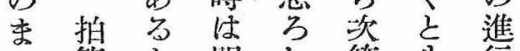
篩 之 明 L 第安行 全器言瞭く $飞$ 時 然のつ落全間 器 第音 $\tau$ 多難體的秩 一昌上面で之に序 期合い的あしはで 意己っでるで局

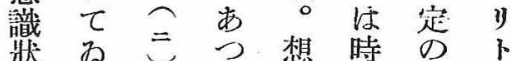
態る所た起間順义

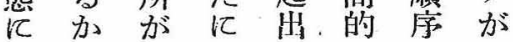



艻數 值 几 月二て は 期 あ 起 言參でる 幾規 寸 關乃期來狆飞方子期照あ急ら則言て 乙 至

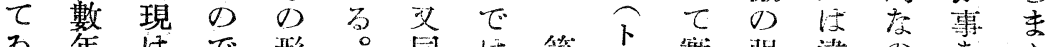

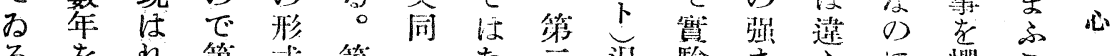

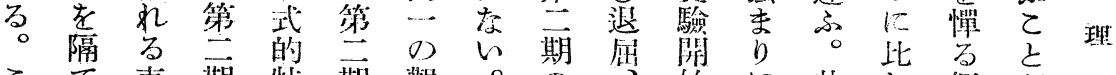

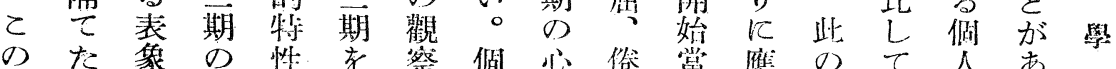

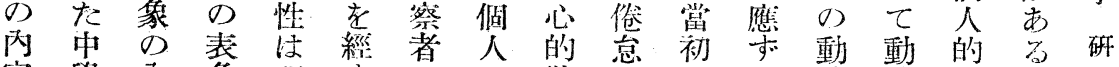

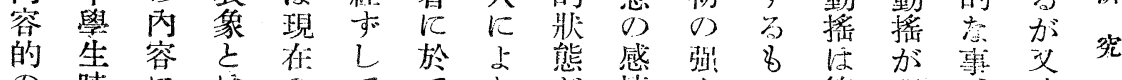

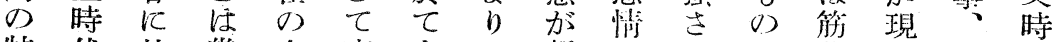

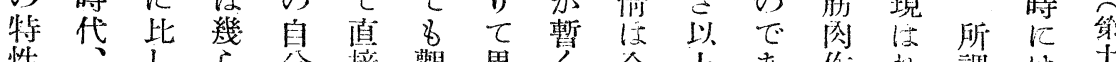

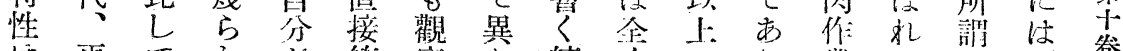

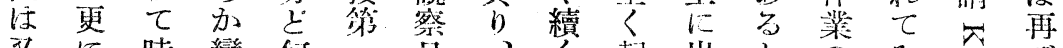

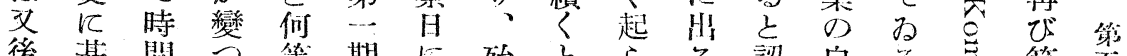

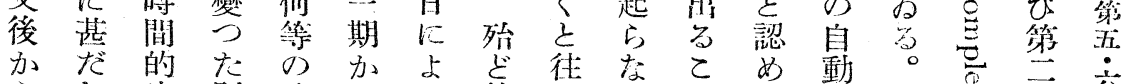
5 L 空 别連 5 b 第芯

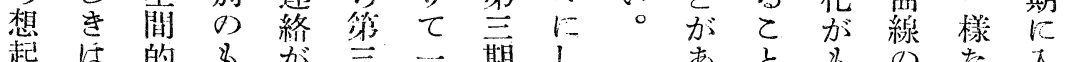

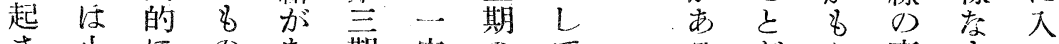

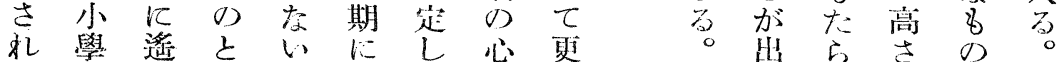

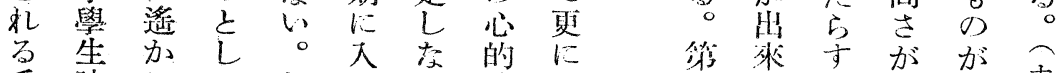

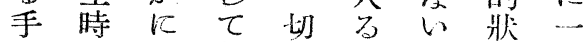
が代 現氣狆と。態步

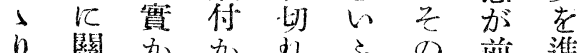

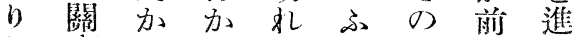

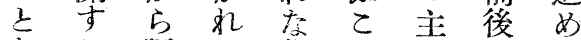

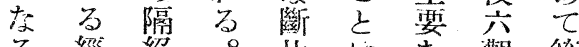

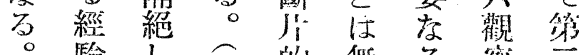
が驗して 父的無方

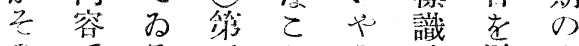

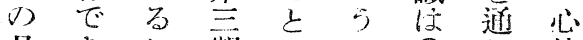

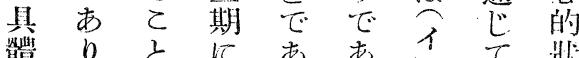

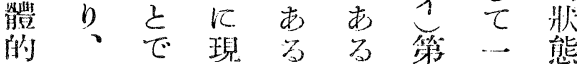

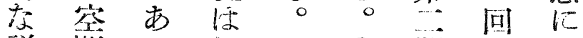

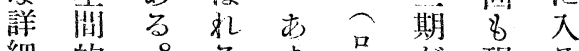

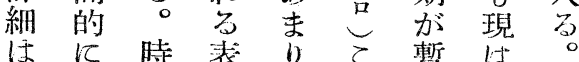

活に時 表 笓東的方緕期續 な

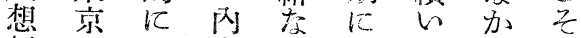
起应容く於てつ狆 さか

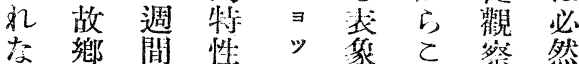

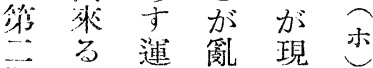

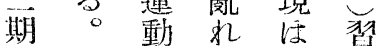
の乙 衝て れ 慣 曲の動來方昫 線 雷 00 る

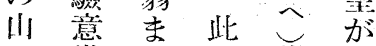
の)識 b 0 作 起

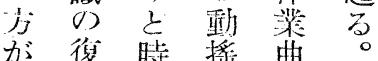

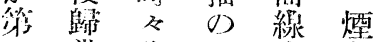
… 得程 蒜 期 時跕度 檢 が 上に应等吞 b於る侗后み

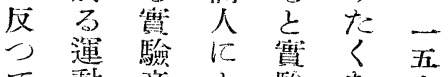
て動急占噞怘共 高 衝 識 b 閶る

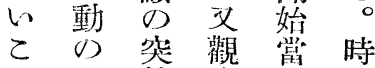
乙 出 然 憼 罍 時 がさの自の法

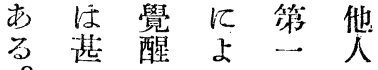




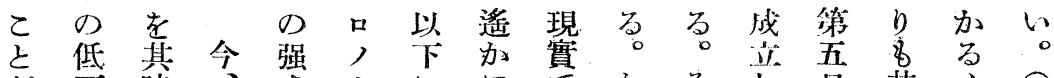

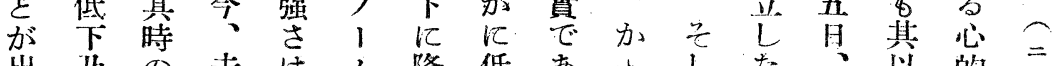

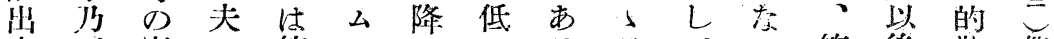
來至實 第の る

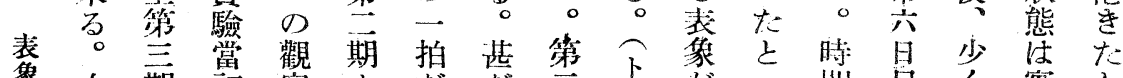

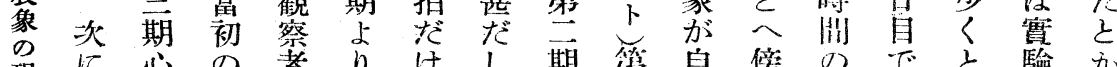

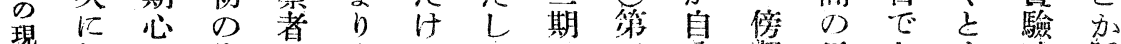

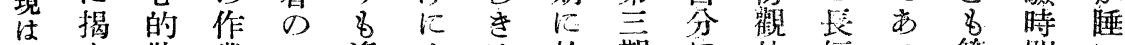

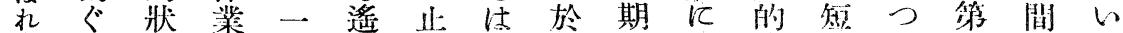
方る 態曲々加ま全るす現でにて三十之

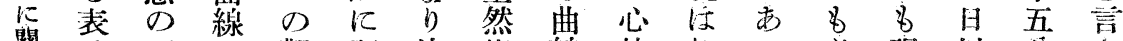

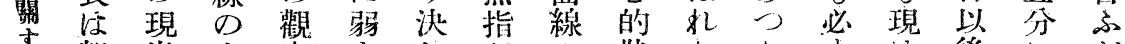

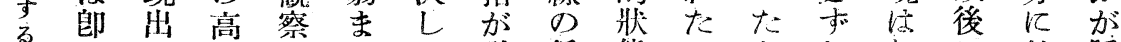

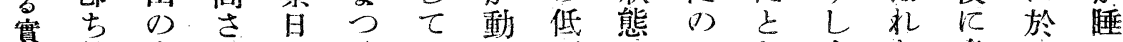

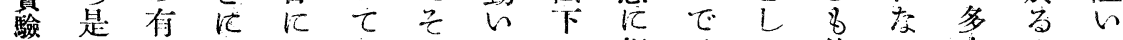

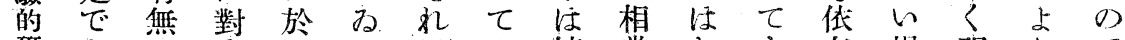

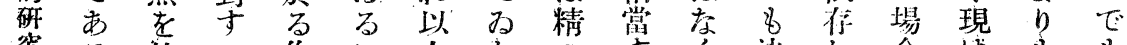

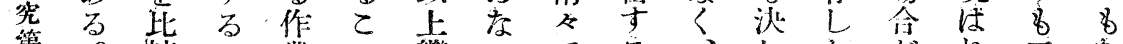

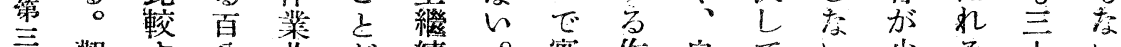

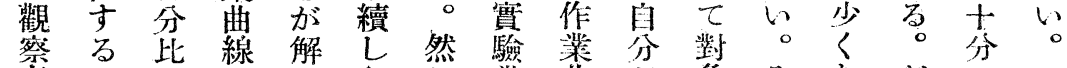

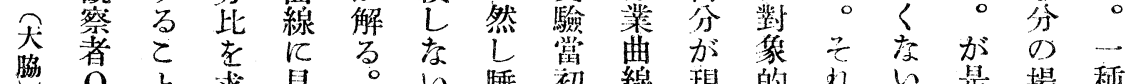
苏 $\mathrm{O}$ 求見。 之がめ出第乙服の貫では。合特

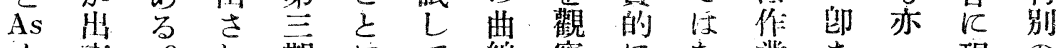

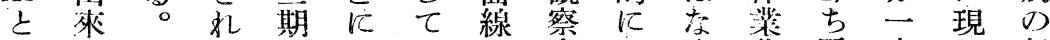

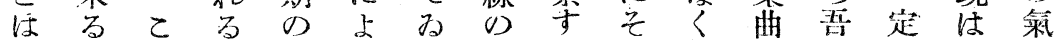

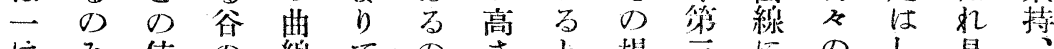
榢 み 值 の

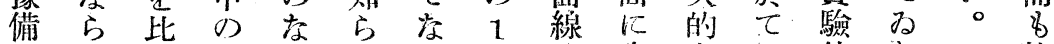

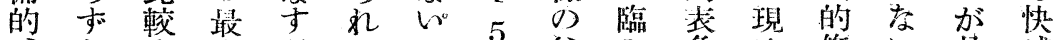

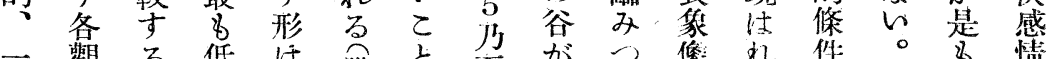

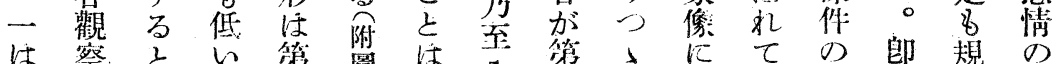

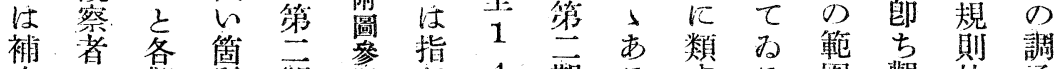

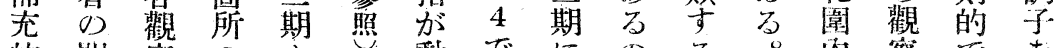

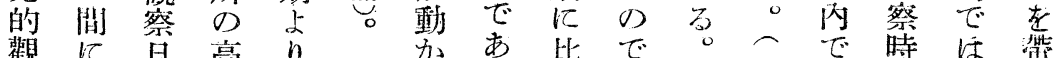

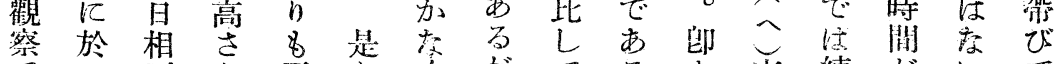

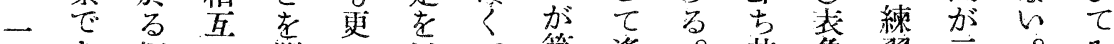

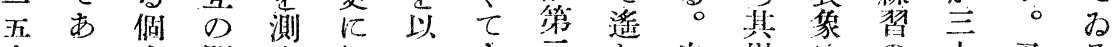

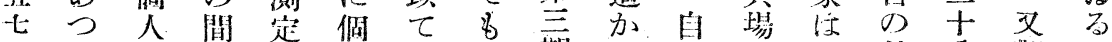
$\tau$ 的飞等性觀之期飞而目效分觀ら

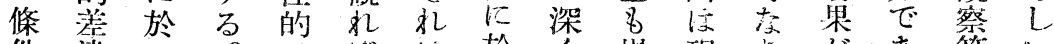

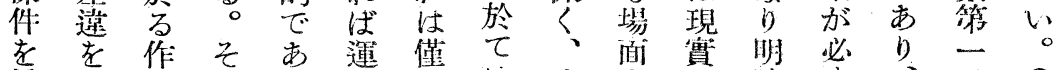
黄 鼻 番 己

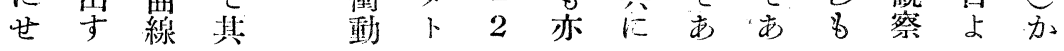




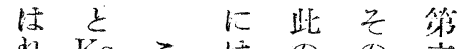

犯 $\mathrm{Ks}$ は の, の六

得での低結他 H

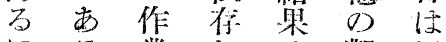

に方業しは觀反

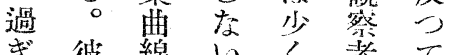

き彼線いく者て

な 等 の乙过反

いる最之多何動

課低索此就的

是題の示 $の$ \&

はの音专實此非

乙意さも驗の常

\begin{tabular}{|c|c|c|c|c|c|}
\hline $\begin{array}{c}V_{p} \\
V_{t .}\end{array}$ & $\mathrm{Km}$ & s & $\mathrm{Am}$ & $\mathrm{Ks}$ & $\mathrm{Az}$ \\
\hline I & 80.6 & 38.0 & 20.6 & 60.0 & Tis.0 \\
\hline II & 68.7 & 42.5 & 0 & 50.0 & 54.1 \\
\hline III & 51.3 & 35.7 & 31.8 & 32.5 & 49.9 \\
\hline IV & 75.0 & 13.3 & 33.3 & 40.0 & 52.0 \\
\hline $\mathrm{V}$ & 32.3 & 0 & 28.6 & $52: 5$ & 26.6 \\
\hline VI. & 15.6 & 46.0 & 6.0 & 71.8 & $5 \pi .7$ \\
\hline
\end{tabular}

識は任の的期に

整 の 觀 で條待高

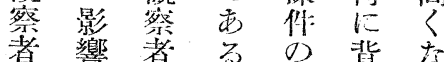

得

心

理

學

研

が 作 の

實 肘 個

駿 が 性

者割苍

の 合 誠

呚に泟

示長 赤

をく裸

割 續 队

合以に

にて 現

灾觀は

等 L

逝第 乙

b 五

にH

梁公連

离是動

取的

り 䔬こ衝

驗て 動

意秒 打

識 $5 \sigma$

父 籍 驾

は $三 \omega$

日 期 0

的的医

㱔 心 嚁

芜的繁

が爿堵

强 態 $\mathrm{Km}$

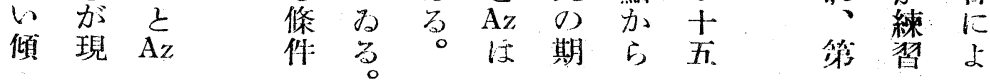

籁

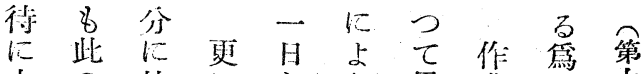

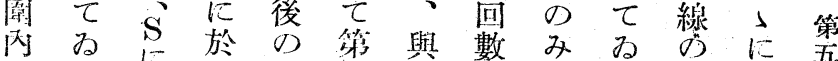

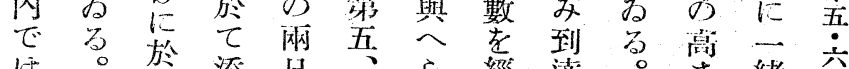

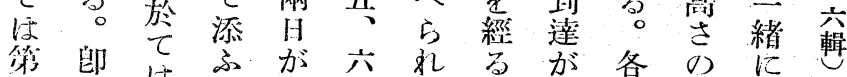

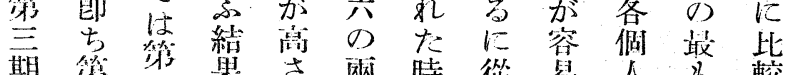

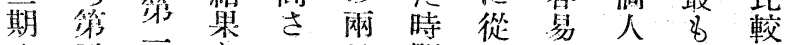

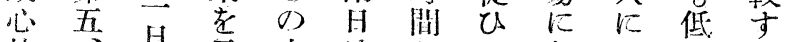

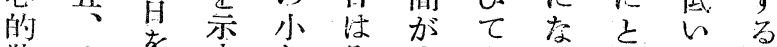

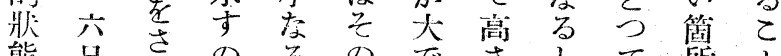

態

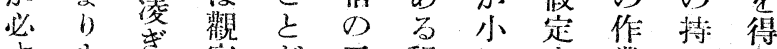

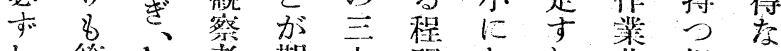

L 第 $\mathrm{A} z$ 者 期市現な狆曲相

8四に $\mathrm{Km}$ 待分は㟔線龂の

練 H 於上さが扎傾觀㐫的で

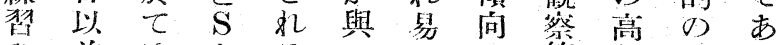

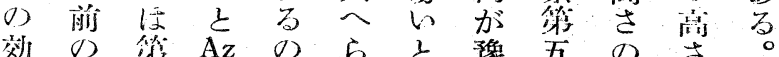

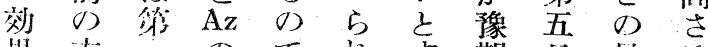

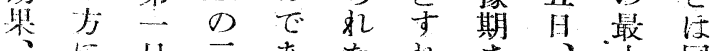

ににH者た好さ、同

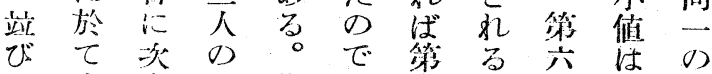

に小ぐみそあ—。第 觀

時な高で礼る

清马位尔加少於期者

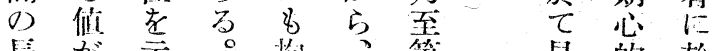

是加示。拘?第 見的於

智位 $L$ がらて四壯狀て

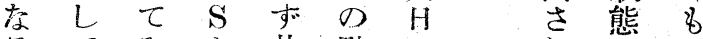

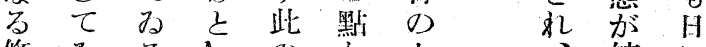




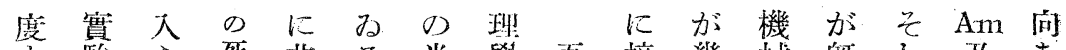

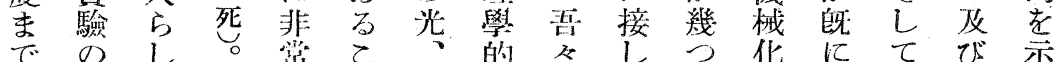

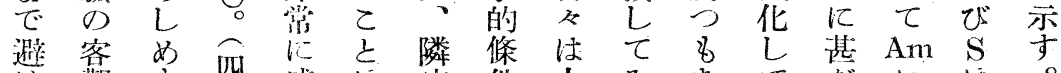

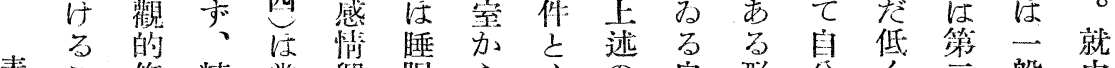

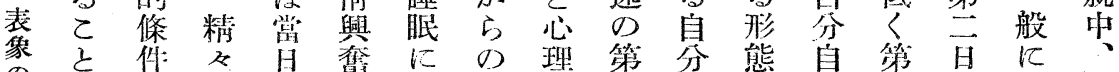

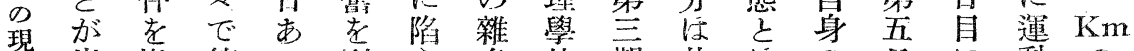

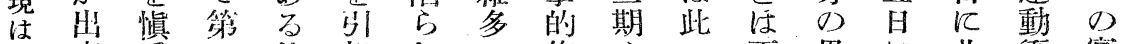

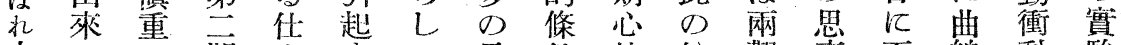

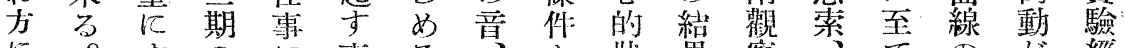

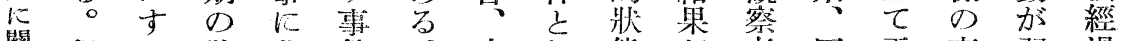
關但る 炣非件。身し 態が者回零, 意弱過

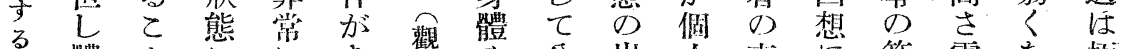

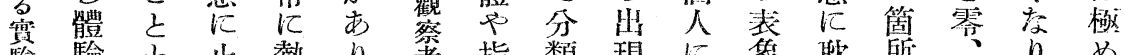

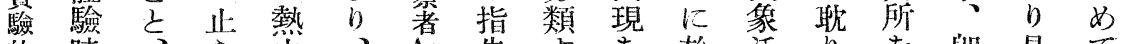
的時、方等、As 先守を於活b考郎易て

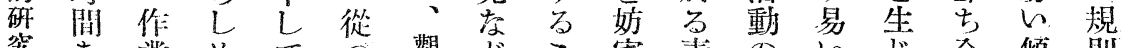

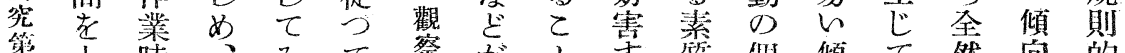

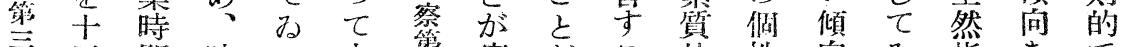
五間時る本第窮㤎る的性向み指をで

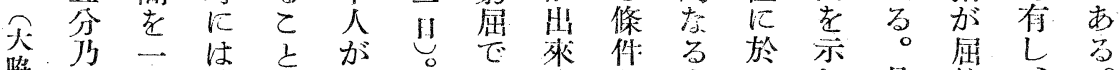

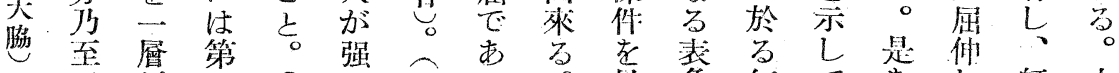

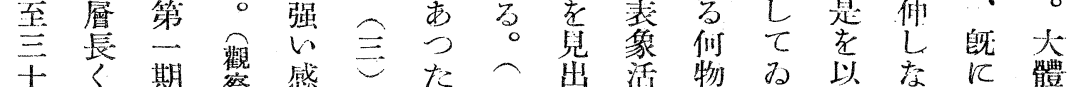

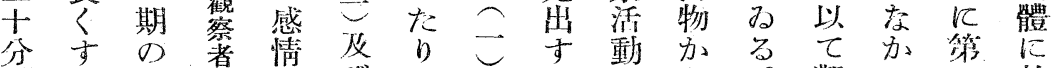

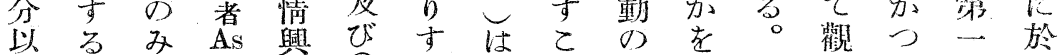
上乙で觀隹 四る物之傾物而処た回て

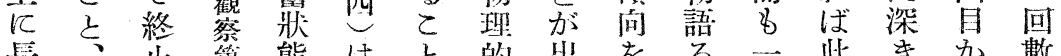

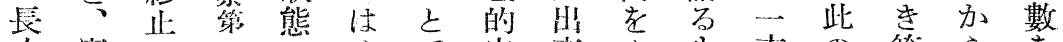

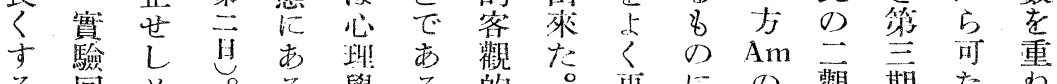

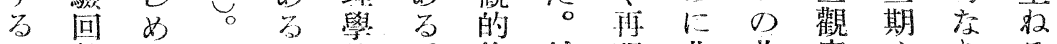
乙 數る以と的。條妨現非曲察心方豆

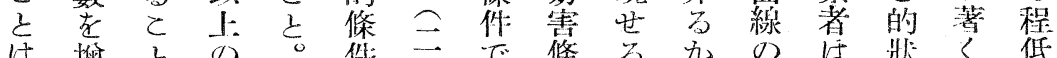

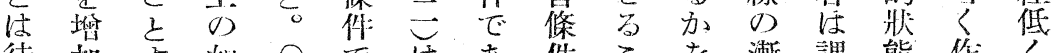

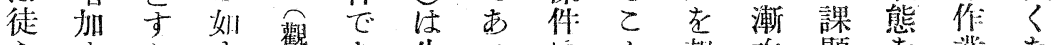

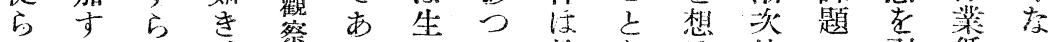

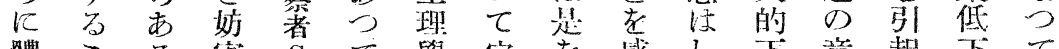

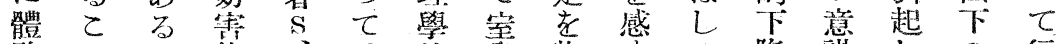

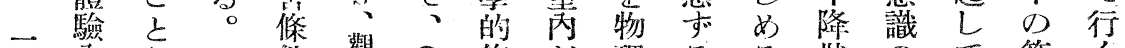

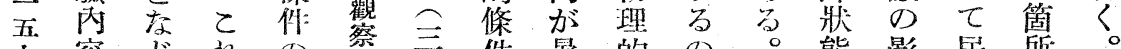

九 容を机の祭三件暑的の態影居所

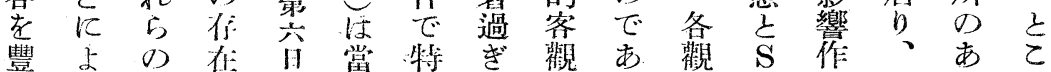

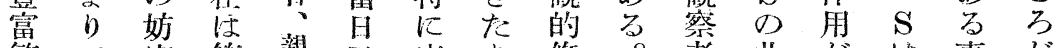
繁て 害第数父疲り條。者曲がは 事が

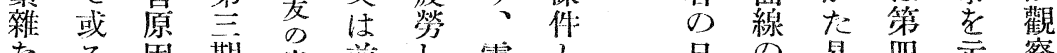

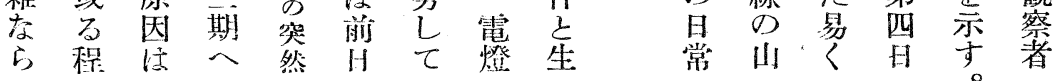


憋 其

想初集 䀢

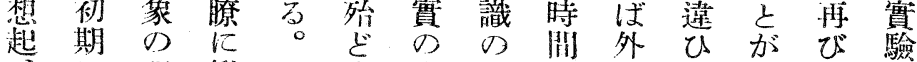

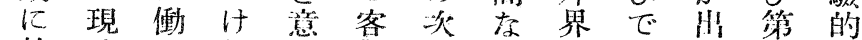

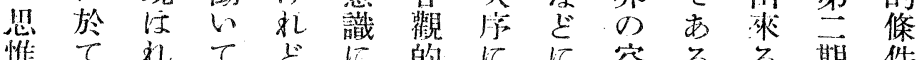
惟て れて

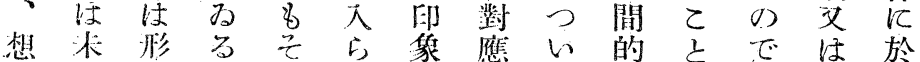

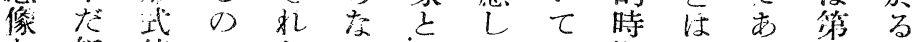

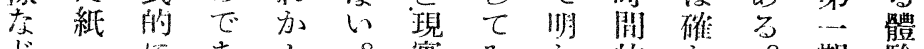

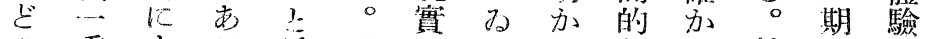

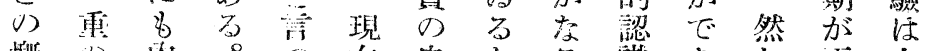

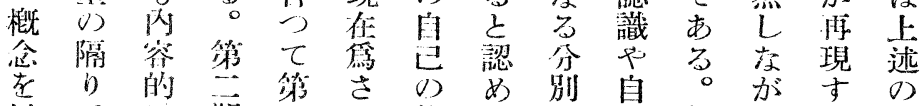

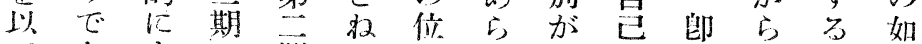

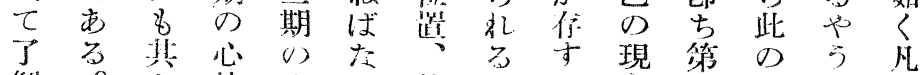

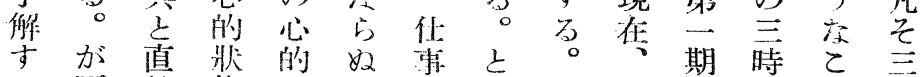

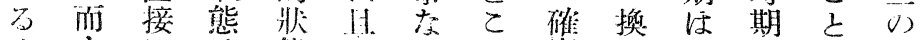

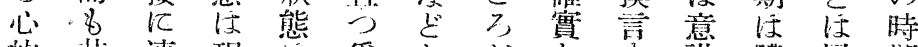

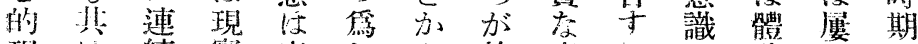

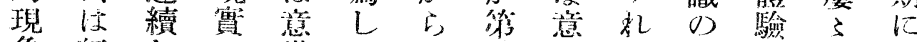

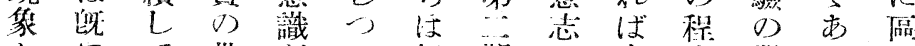

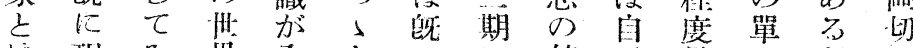
圳現妿界金あに統山最ながる 相墨 る

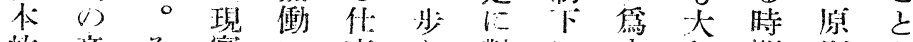

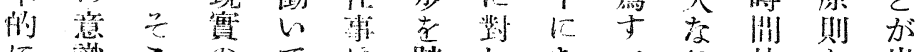
潩諓方

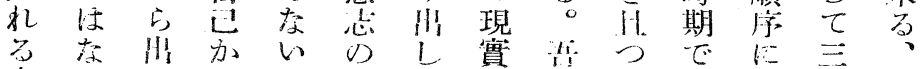

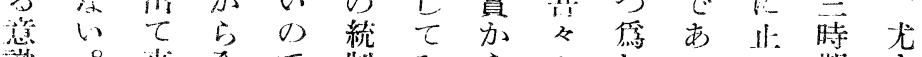

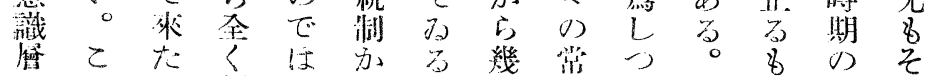

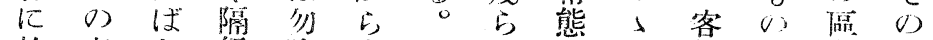

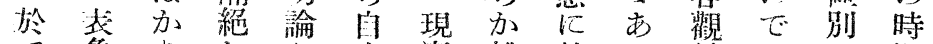

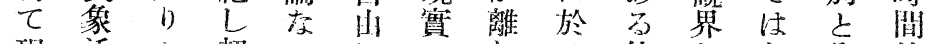

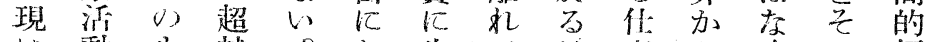
以動名越。友て

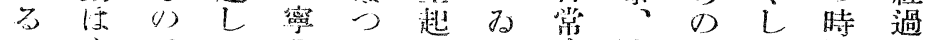

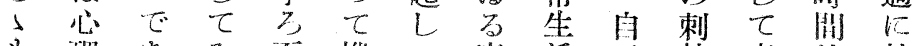

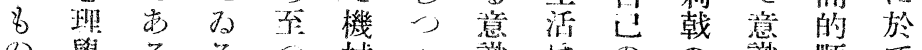

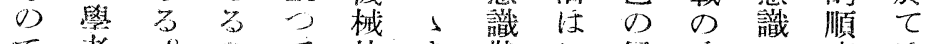

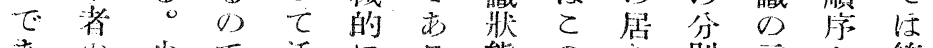

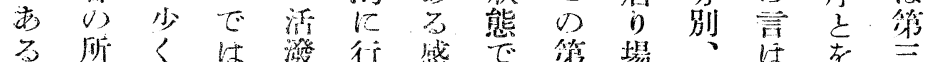

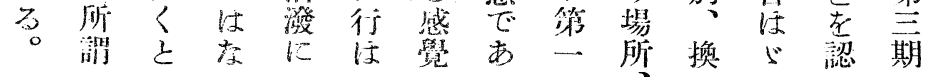


力るき聯許と印が所た名切絡表そ

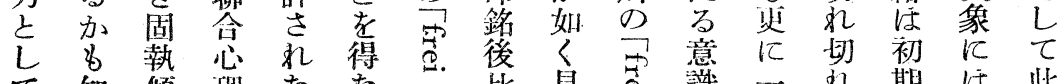

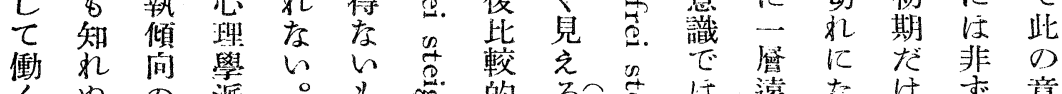

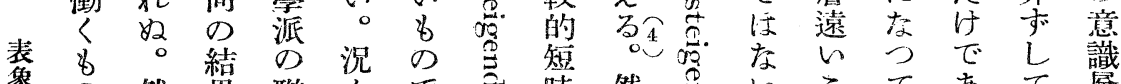

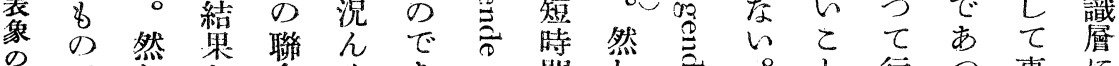

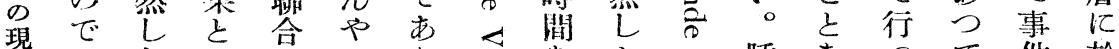

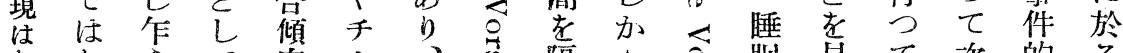

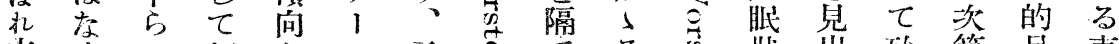

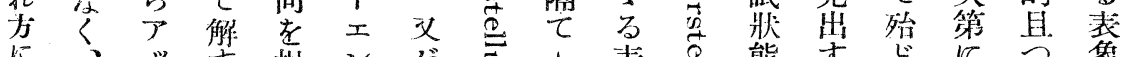

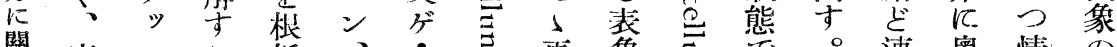

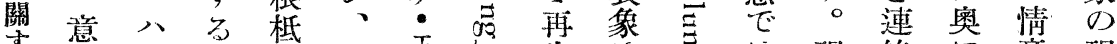

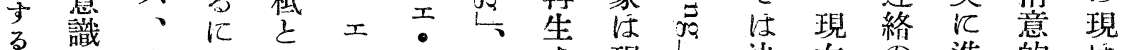
實をを汇し、ビミキさ現に沃在の進的は

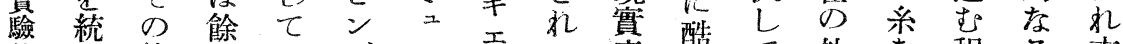

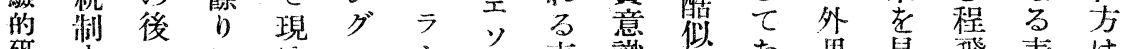
研吉コには八!、フ表識似李界鼠飛表は

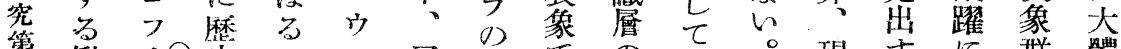
忽働汃史小不了自での現す群體

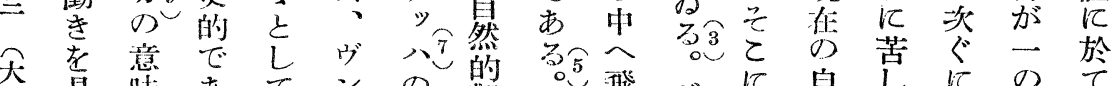

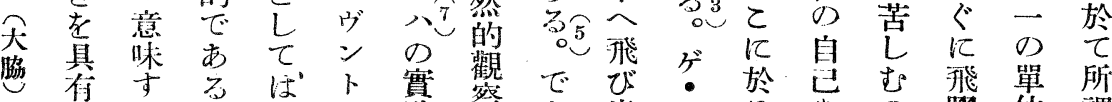

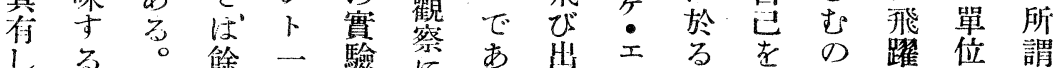
な如人り 派的現る

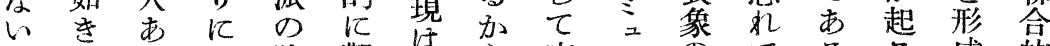

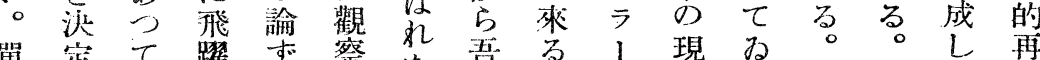

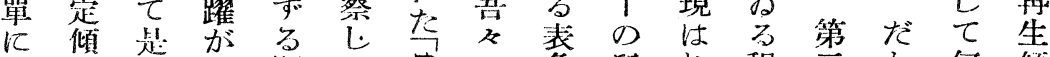

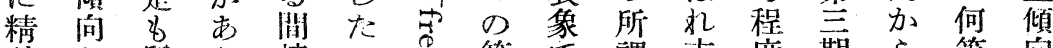
神之所 b 接—Q. 第芯謂方度期 5 等向

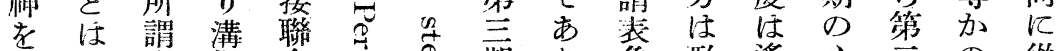

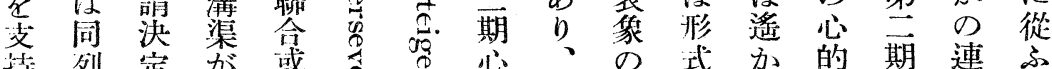

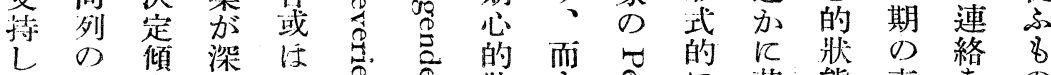

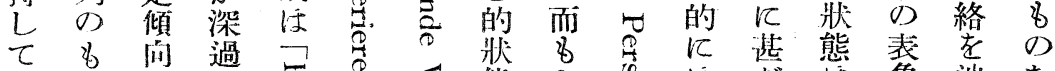

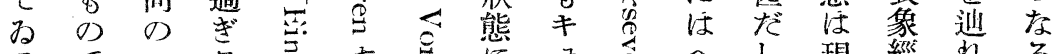

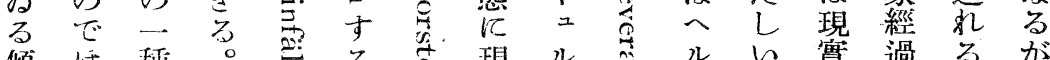

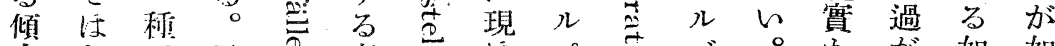

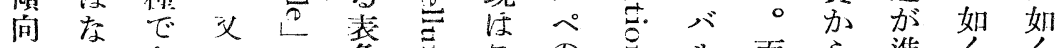

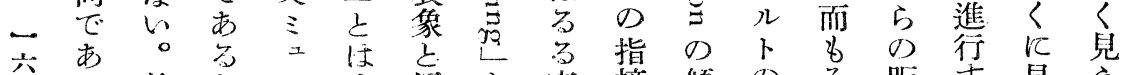
六然是之

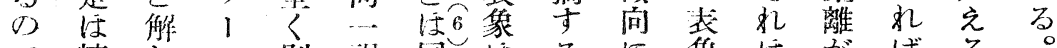

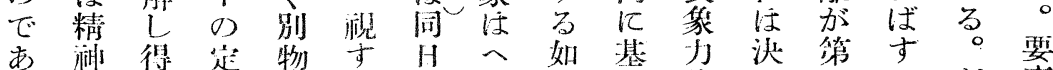

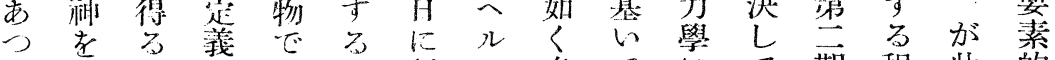

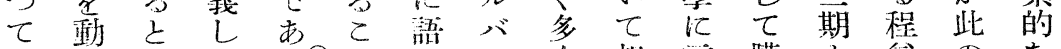
精 吕楥 た 


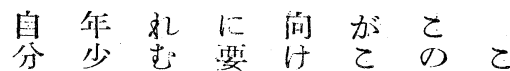

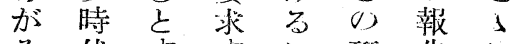

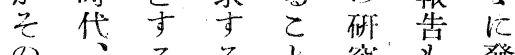

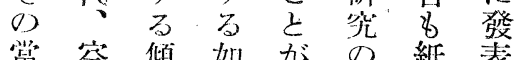

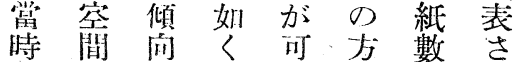

の的が自能法怒抗

自に根分で論制た

分は强にあ的限意

に故く汇原の志

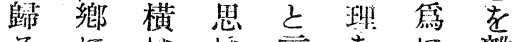

るにはほ言をに離

の 籃つ礼方以叙狆

ですてる磼て述た

ある。信す不心

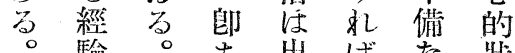

唯驗現吾萊從尔笲

だ容在々た來㩆に

日芯にの殆の於

常位直意々篦々

生 L 接識 ᄂ 科索表

活て心內 $て$ 學つ爱

にる理に既的たの

於る學任に研。現

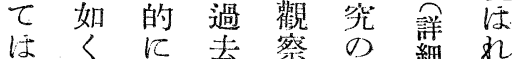

現に接のさ及方

䁇見せ體狄ば東の

のえる驗たな北研

客方體內 範出帝笔

觀。驗容園》國は

界之加加內た 學固

の礼方化精学

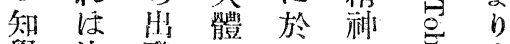

學決發艺宁完

L $L L$ 於 8 米公成

職 $\tau \tau$ 不知元

览表最時觉の域

的售後䦌結機导に

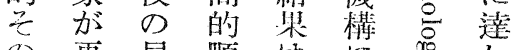

の 再 局順 は

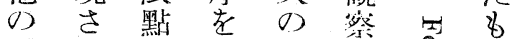

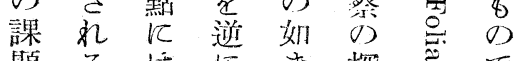

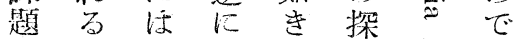

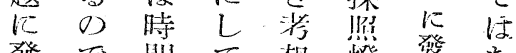

發で閶て 想燈登况

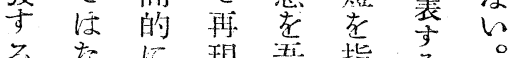

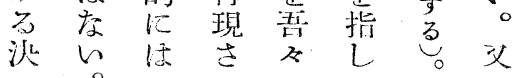

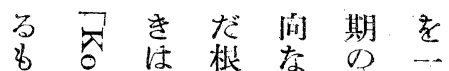

○)

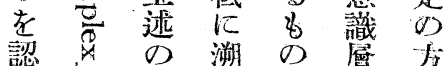

訫

る唯きて 第於代心

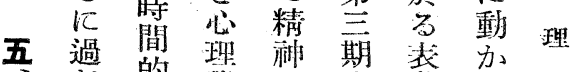

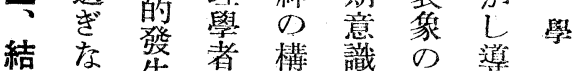

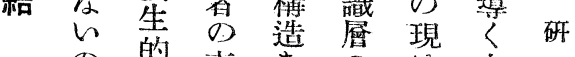

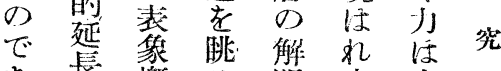

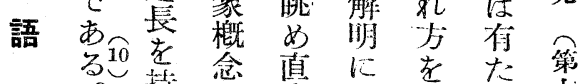
る。持念直役音たな第

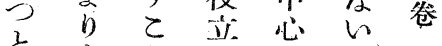

考

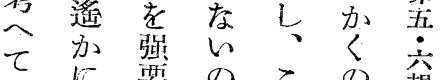

み

名人さ注の如

が開机寧

吾深分怪於合

々 部でしる 的

の䆏あむ現再

觀造名に垡生

察愿。足老傾

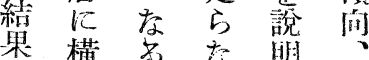

に程い专周

占所。乞゙執

狄孞謂染く的

ば如吉々 想俩

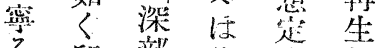

万印部之点傾

第集心穴向

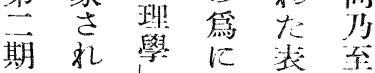

のるに ほ集沃

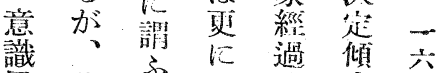

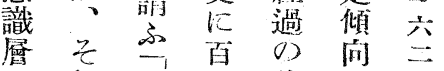

にL 无訬 0

於て高等法如

て $气$ 顽 刑き

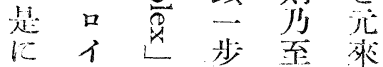

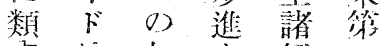




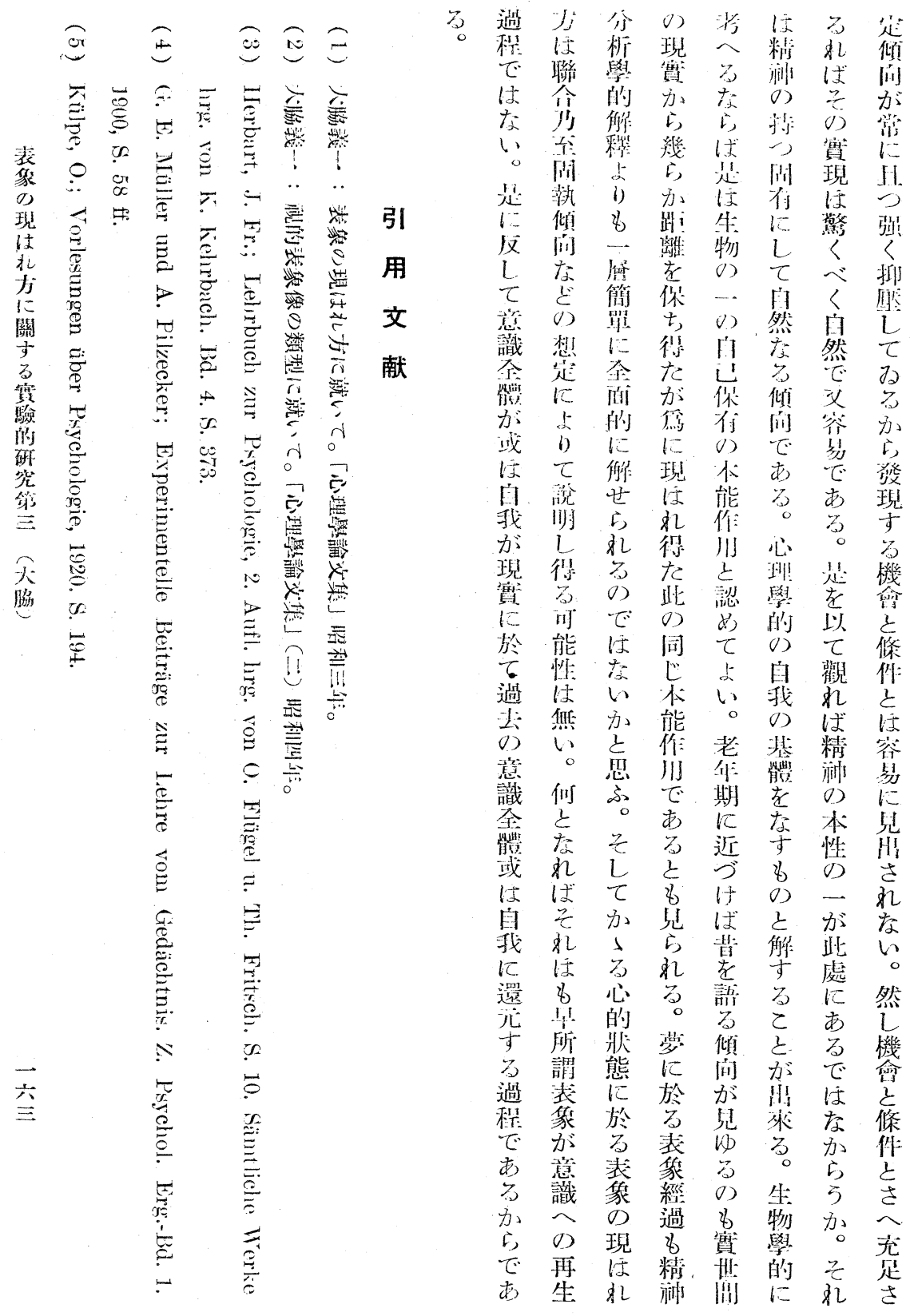




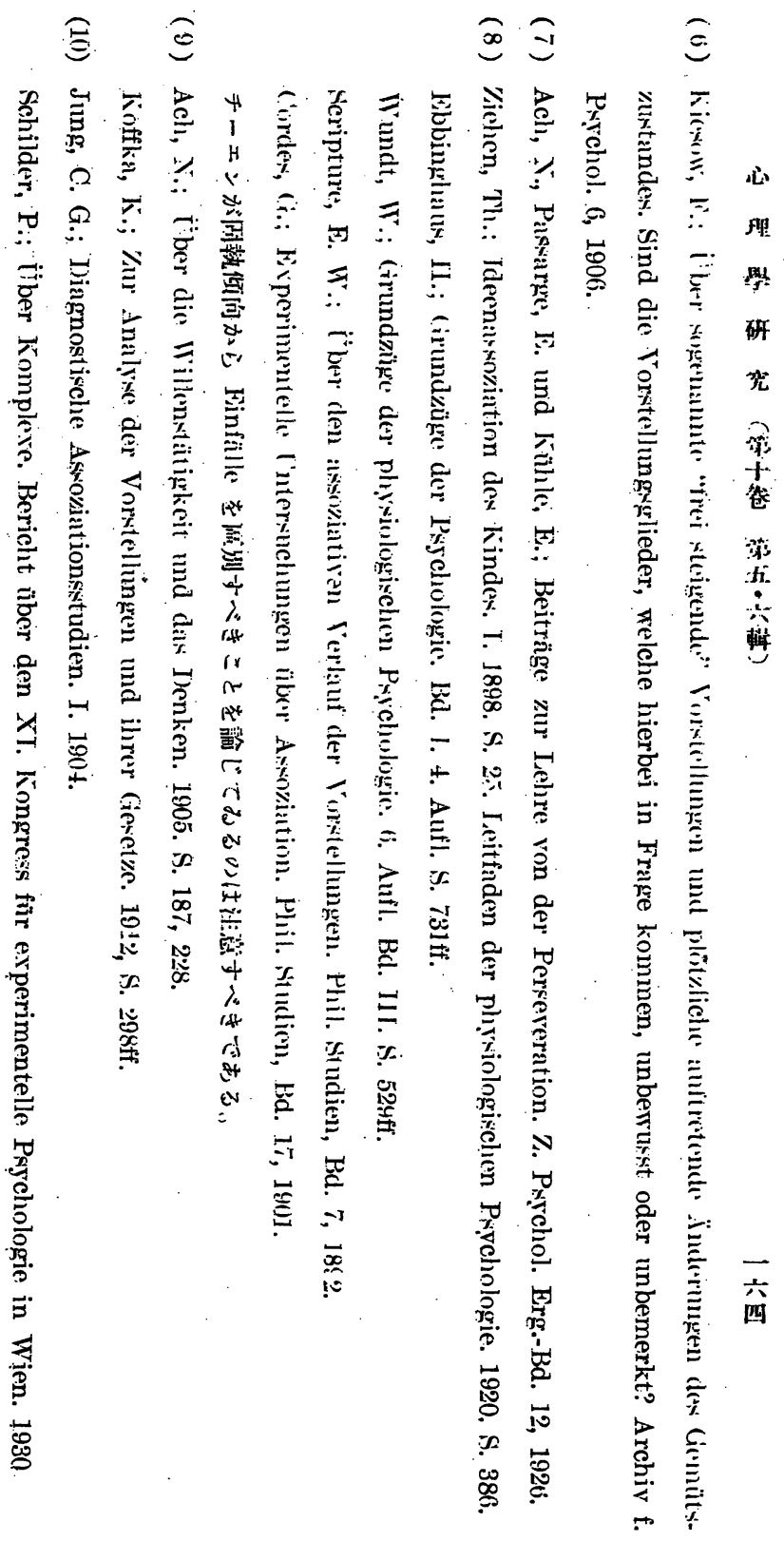


(From the Psychological Institute, Tôhoku Imperial Cniversity)

\title{
Experimental Studies on the Appearance of Presentation (III)
}

\author{
(Abstract) \\ by \\ Yowikam Ohwaki
}

I. Object of study: When no sensory impressions, for example stimulus words, are given to us, and when no special volitional attitudes are taken by us, what sort of presentations then comes to us naturally and spontaneously? We want to study the appearance of these presentations.

II. Methor of study: We will study not by means of suggestions or any other technique, but by means of any familiar procedure in psychology. And we must gain besides not only subjective introspective data, but somewhat objective material able to infer the following of presentations. We thought of a method, then, meating the demand. That is the method of muscular work on Vowo's ergograph. In dark room and without experimenter one draws a light weight $(530 \mathrm{gr})$ rhythmically 15 to 30 minutes according to slowly tact of metronom (56 in minutes), closing the eyes. That is the only work the observers have to do. We have 7 subjects and each observes 6 times in 6 days.

III. Results of obsercation: We can mark of three periods in the following of presentations observed.

The 1 st period: Actual stimuli are perceived. And conciousness concentrates in mucular work. The corresponding waves of ergograph goes in perfect order and the height of them is large (refer the photograph).

The 2 nd period: But before long, conciounness averts from actual work and actual world of perception. One begins to think about things seen or heard just before. Waves of ergograph swing.

The 3 rd period: The 3 rd period comes out abruptly. The contents of presentation bear upon one's older days and native land. Clear is the most images. But very diflicult to recollect the details of them afterwards. Individual differs much about this period. Someone scarcely comes into it. The effect of practice and length of time are not always determining factors. 
The work waves of the period are very low and the form of them most characteristic.

These three periods about the following of ideas is not only difference of period, but difference of, so to speak, order of our consciousness.

IV. Consideration about results: The following of presentations in this work is neither recollection, association nor reflection in ordinary sense. We are not able to explain it with association, perseveration and determination tendencies, not comparable with socalled "complex" of analytical psychologists. That is no reproduction of preventations on our consciousness, but alternations of whole consciousness in its older age. This tendency seems to us to be so natural and spontaneous as to have consider it as a deep nature or instinct of our mind. Full descriptions of the work will be soon published in "Tuhokn Psychologica Folic". 